\title{
Medusa Must Die! The Virgin and the Defiled in Greco-Roman Medusa and Andromeda Myths
}

\author{
By Sharon Khalifa-Gueta
}

\begin{abstract}
Andromeda and Medusa are two types within the same motif - that of the motif of "the woman and the dragon". This article positions a mythical hero between these two women and contrasts their relationship with dragons, along with a further fresh investigation of women and dragons in ritual and cultural context. The complexity of this motif, in contrast to the dragon-slayer topos, is explored, shedding light on social views, desires, and fears toward women in the ancient Greco-Roman cultural context. These female figures are contrasted within one mythical sequence, elucidating their educational role for men. This investigation also confronts the "good" versus the "defiled" woman and clarifies why a "holy-defiled" woman, such as Medusa, cannot exist in patriarchal cultures, and therefore must be isolated, killed, or otherwise controlled by patriarchal society.
\end{abstract}

Keywords: dragon, Andromeda, Medusa, Perseus, myth

\section{Introduction}

The myth sequence of Perseus is well studied, mostly as part of the dragonslayer topos. This article aims to shift the attention from Perseus to his two encounters with females, Andromeda and Medusa, and suggest that by placing them together in the same myth sequence a motif with binary visualisations emerges. While Medusa's image has already been broadly investigated, Andromeda has mostly been neglected, with Perseus's figure gaining the most attention in this myth. Focusing on the artistic manifestation of the syntagm "the woman and the dragon" reveals a Greco-Roman cultural binary of the "good" versus the "bad" woman. The commonality between these two ladies is the dragon: Andromeda has to be separated from it while Medusa is fused with it, which makes the dragon an important sign for the understanding of the underlying motif this myth sequence offers.

Building on the feminist perspective that finds Medusa as an emblem of earlier matriarchal residues that were overthrown by the patriarchy (Culpepper 1986, pp. 22-24, Bowers 1990, pp. 217-235, Dexter 2010, pp. 25-41), the image of Medusa can be explored as a combination of a woman and a dragon; it is not one unified figure but a melding of two separate signs - a woman and a dragon. In the scheme of the "good" versus the "bad" woman, not only was Medusa an

*Post-Doctoral Researcher, Department of Art History-School of History, The University of Haifa, Israel. 
ancient matriarchal goddess who fell from grace, but she also represented a highly dangerous woman, one who was united with a dragon.

The iconologic approach is built upon here by considering the particulars of each image, yet focusing on a broad analysis. The images highlight certain points in the myth, while political, social, and gender, among other aspects, are shoved aside. This article particularly draws attention to the iconographic interface between the woman protagonist and the symbol of the dragon, alongside other symbols that are useful to decipher the meaning of the main motif. Thus this investigation strives to uncover the underlying meanings and functions of the motif in the Greco-Roman context (Panofsky 1955, Baert et al. 2011, Baert 2019, Liepe 2019).

This analysis is based on rich academic literature that investigates ancient dragon images and myths, mostly focused on the dragon-slayer topos. Nevertheless, this investigation of the motif (syntagma) "the woman and the dragon" is the first of its kind, epistemologically approaching the feminine interaction with the dragon (DeVault 1990). Pertinent is a line of inquiry that Daniel Ogden explores in his book Drakōn, presenting several cases of what he calls "Masters and Mistresses of drakontes." Although he does not generally note the genders of dragon masters and mistresses, Ogden does stress the different approach and behavior of specific female figures toward dragons (Ogden 2013a, pp. 192-214). Apart from Ogden, there are several more studies focused on women and dragons and the relationship between them. Deonna's (1949) article, engages with research from the early twentieth century on this subject, seeking to understand an enigmatic miniature sculpture of a maiden under a tree encircled by a serpent. Early twentieth-century books such those of Saintyves (1908) and Reinach (1905) present relevant documents. Finally as, Pailler's (1997) article, explores the status of Vestal Virgins in light of "virgin and serpent" ritual traditions (Reinach 1905, pp. 178-180, Saintyves 1908, Deonna 1949, Pailler 1997).

This article presents the literary and artistic manifestations of Perseus myths in Greco-Roman cultures and contrasts the hero's approaches toward Andromeda versus Medusa. This study examines the myths over a long period of time but does not underestimate the uniqueness of each period and culture of the Greco-Roman era, which manifest their own particular patriarchy. Instead a common thread of approaches toward women is emphasized. Moreover this article goes extreme lengths to outline the singularity and changes of each period and still seek the shared ground on which they founded their artistic approach to the images of this myth. Examining the same hero portrayed in two opposite "female and dragon" situations extracts the complex meanings and sociocultural value of the interaction between a female figure and a dragon. In this manner, visual evidence is stressed as key to tracing the residues of matriarchal goddesses in Greco-Roman patriarchal context.

\section{Andromeda}

The myth of Andromeda and Perseus appears very early in Greek art but later in literature, although linguistic and folk investigations trace it back to Sanskrit and 
Mesopotamia. In almost every culture worldwide, a dragon-slayer topos exists, but every culture emphasizes different issues within it. Although the myth is very simple, its details, particularly the visual ones, diverge over time. These changes in the motif reflect the changing set of values and morals of its cultural context.

Ovid's Metamorphoses was written as late as the first century AD, but may nonetheless be the best surviving literary source for the Andromeda myth. Ovid tells the story achronologically, starting with Andromeda and going back in time to Perseus's encounter with Medusa. This choice highlights the comparison between two disparate encounters of women and dragons and stresses the two female figures' differences. This article follows Ovid's lead in the narrative development.

First, the Andromeda myth must be outlined: While fleeing the Gorgons over Ethiopia, Perseus sees a beautiful maiden being offered as a sacrifice to a sea dragon named Ketos. This is Andromeda, the daughter of King Cepheus and Queen Cassiopea (Cassiepeia), who pays the price for her mother's vanity. Cassiopea had boasted that Andromeda was more beautiful than the Nereids, sea nymphs that often accompany Poseidon. Perseus falls in love with Andromeda, wants to save her, and approaches her father to ask for her hand in marriage. Cepheus agrees, concealing from Perseus the fact that Andromeda has already been promised to her uncle Phineus (Taplin 2007, p. 176). Although he possesses the deadliest weapon in the ancient world - the head of Medusa-Perseus chooses to confront and slay Ketos (mostly identified as a female in literary sources) with his harpe (a bent sword). After liberating Andromeda, Phineus and his entourage confront Perseus, renewing the claim of Andromeda's uncle to her hand. This time, Perseus chooses to use Medusa's head, turning all his opponents into stone. Perseus and Andromeda are married (Ovid 1998, pp. 94-106, 4: 663-739, 5: 1235, Gantz 1996, pp. 307-309, Watkins 2001, pp. 297-438, Ogden 2008, 2013a, p. 124).

Evaluating Perseus and Andromeda's iconographic development, together with literary evidence of this myth, is required. This survey uses only examples from the main iconographic thread, considering instances with iconographic significance. The first evidence of the Andromeda myth is imaged on a Corinthian amphora dated 575-550 BC (see Figure 1) (LIMC 1981-1999, vol. 2/1, pp. 77490 , vol. 2/2, pp. 622-642), showing Perseus, identified by name, taking aim with what look like circular stones at a huge doglike Ketos and carrying a bag assumed to contain Medusa's severed head. Andromeda, also identified by name, stands on the right, seemingly tied. Perseus is presented as black, as is typical for a male figure on black-figured vases. Both Ketos and Andromeda, atypically and intriguingly, have white skin that associates them and stresses, even in this early moment, the assimilation between the female protagonist and the dragon (Ogden 2013a, p. 124). 
Figure 1. Perseus and Andromeda, Late Corinthian Black Figure Amphora, 575$550 \mathrm{BC}$

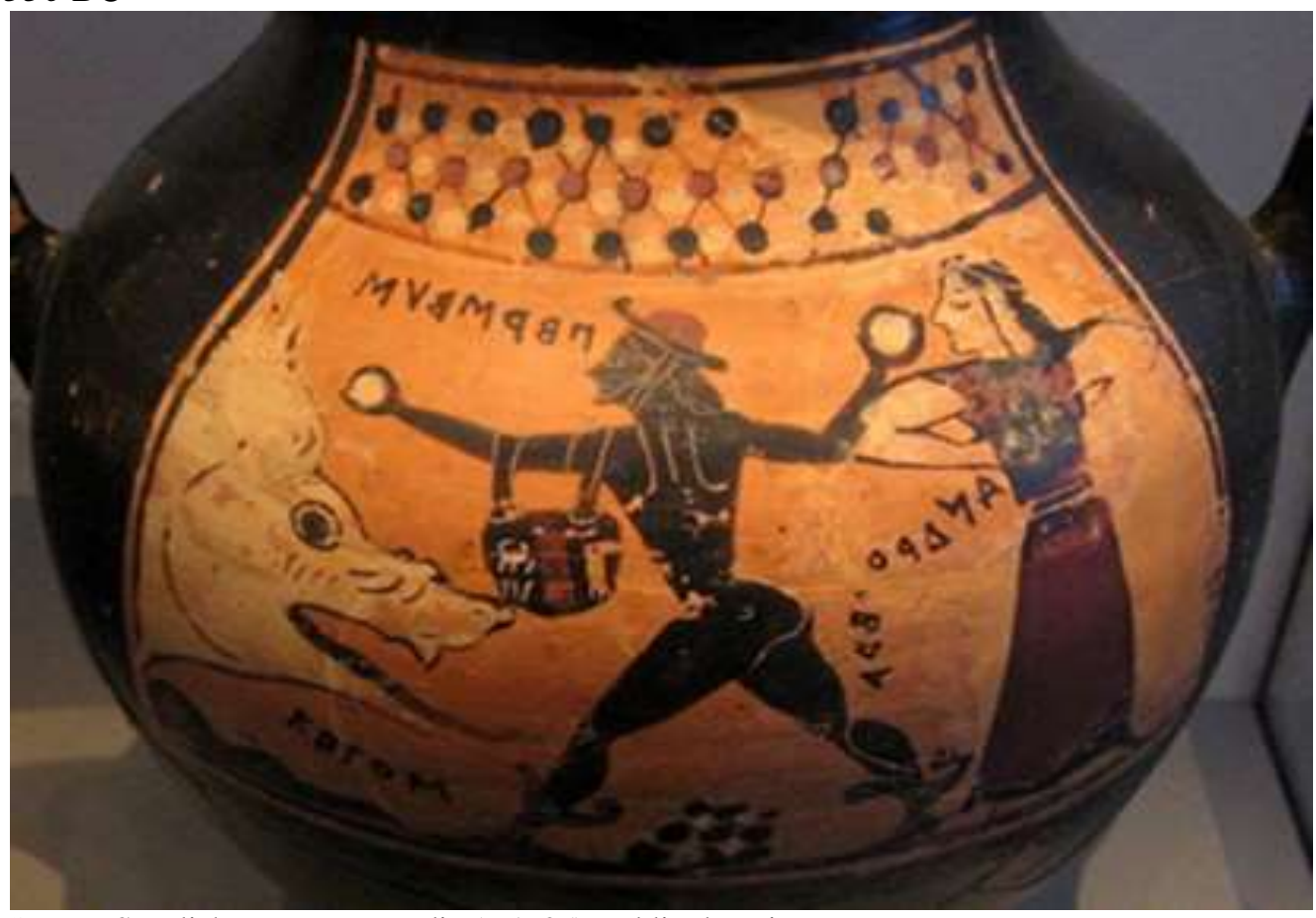

Source: Staatliche Museum, Berlin (F.1625). public-domain.

The earliest literary evidence of the Perseus and Andromeda myth is Hesiod's Catalogue of Women, which merely mentions them as a married couple (Hesiod 2018a, pp. 162-165: F135 MW, Ogden 2013b, pp. 162-170). The first evidence of their narrative is fragments of tragedies by Sophocles and Euripides (Carden 1974, pp. 236-243: figures, 126-136; Euripides 2004, vol. 2, pp. 133-168: ffl. 15a, 120, 129, I29a, 136, 145, 146, Snell 1971-2004, vol. 1, p. 69: 1009-1135, p. 212: T1. fr. $33 \mathrm{~K}-\mathrm{A}$, Ogden 2013b, pp. 108-111, 162-169). Various pieces of literary and visual evidence suggest that the myth was similar to Ovid's version.

Phillips's (1968) article identifies several iconographic types throughout the Greco-Roman era. The present study, although inspired by Phillips's work, offers a different division: The first type relates to the tragedy of Sophocles as manifested in five Attic vase paintings, four of which were discovered in Italy and are from before $430 \mathrm{BC}$. These Attic paintings are echoed by numerous vases found in Sicily, probably from Tarentum. Phillips suspects these vase paintings were all based on a large and well-known wall painting in Athens. These vases portray the process of binding Andromeda to one or two wooden posts, a capital punishment in Athens, Phillips notes. This can be seen in an Attic pelike, produced in the workshop of the Niobid painter around 460 BC (see Figure 2), that presents Andromeda being bound to a pole by a black African servant, stressing that the scene takes place in Libya (Hoffmann 1963, vol. 61, pt. 325, 108-109, Phillips 1968). 
Figure 2. Workshop of the Niobid Painter, Andromeda, Red-Figure Attic Pelike, c. $460 \mathrm{BC}$

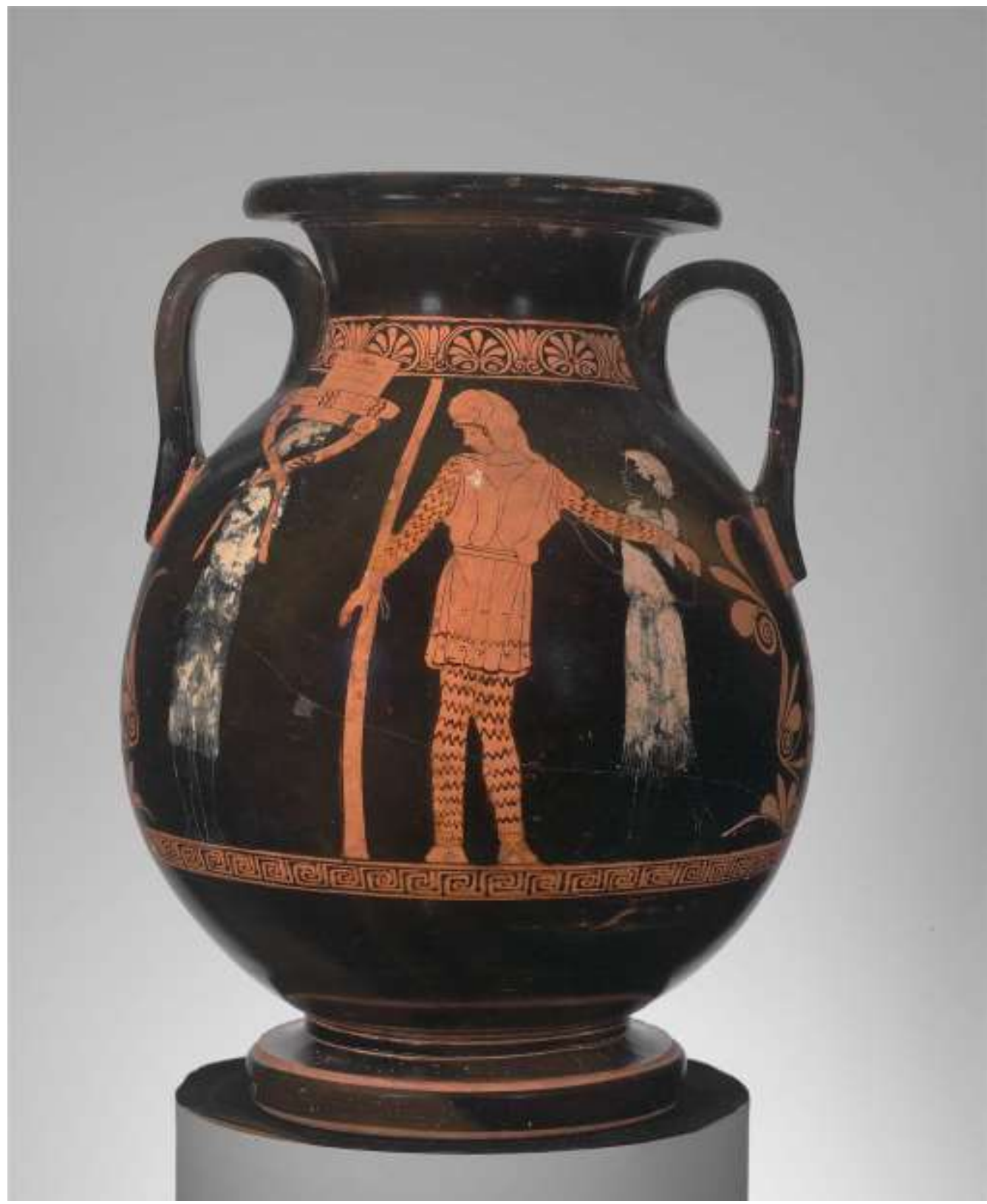

Source: Museum of Fine Arts, Boston (63.2663). (C) MFA public domain: www.mfa.org: https://collections.mfa.org/download/153843;jsessionid=4B48C60C3190486FB3E0BB4439436091

A second group of vases recovered from southern Italy presents Andromeda tied to a cave entrance, as exemplified by a Campanian red figure hydria (see Figure 3). Ogden sees the transformation of the iconography, from Andromeda being tied to posts to being attached to a rock, as a shift from her appearance in the play of Sophocles to that of Euripides (Carden 1974, pp. 236-243: figures. 126136; Euripides 2004, vol. 2, pp. 133-168: ffl.15a, 120, 129, I29a, 136, 145, 146; Snell 1971-2004, vol. 1, p. 69: 1009-1135, p. 212: T1. fr. 33K-A, Ogden 2013b, pp. 108-111, 162-169). As Sophocles presents her, Andromeda is tied to one or 
two posts, an iconography that arrived in southern Italy (mostly present in Sicily) from Attica and lingered there. Meanwhile in Athens a new iconography was introduced that echoed Euripides's play in its portrayal of Andromeda bound to a rock or cave entrance (Ogden 2008, pp. 69-71). Phillips presents the conceptual connection between the poles and the entrance of the cave by enumerating myths in which the entrance of a cave serves as a place of death, such as those of the demises of Eurydice, Actaeon, and Philoctetes. He also presents a calyx crater that depicts Dirce dragged to her death under an arch of trees resembling a cave entrance (Phillips 1968, p. 11).

Figure 3. Perseus and Andromeda, Campanian Red Figure Hydria, 375-350 BC

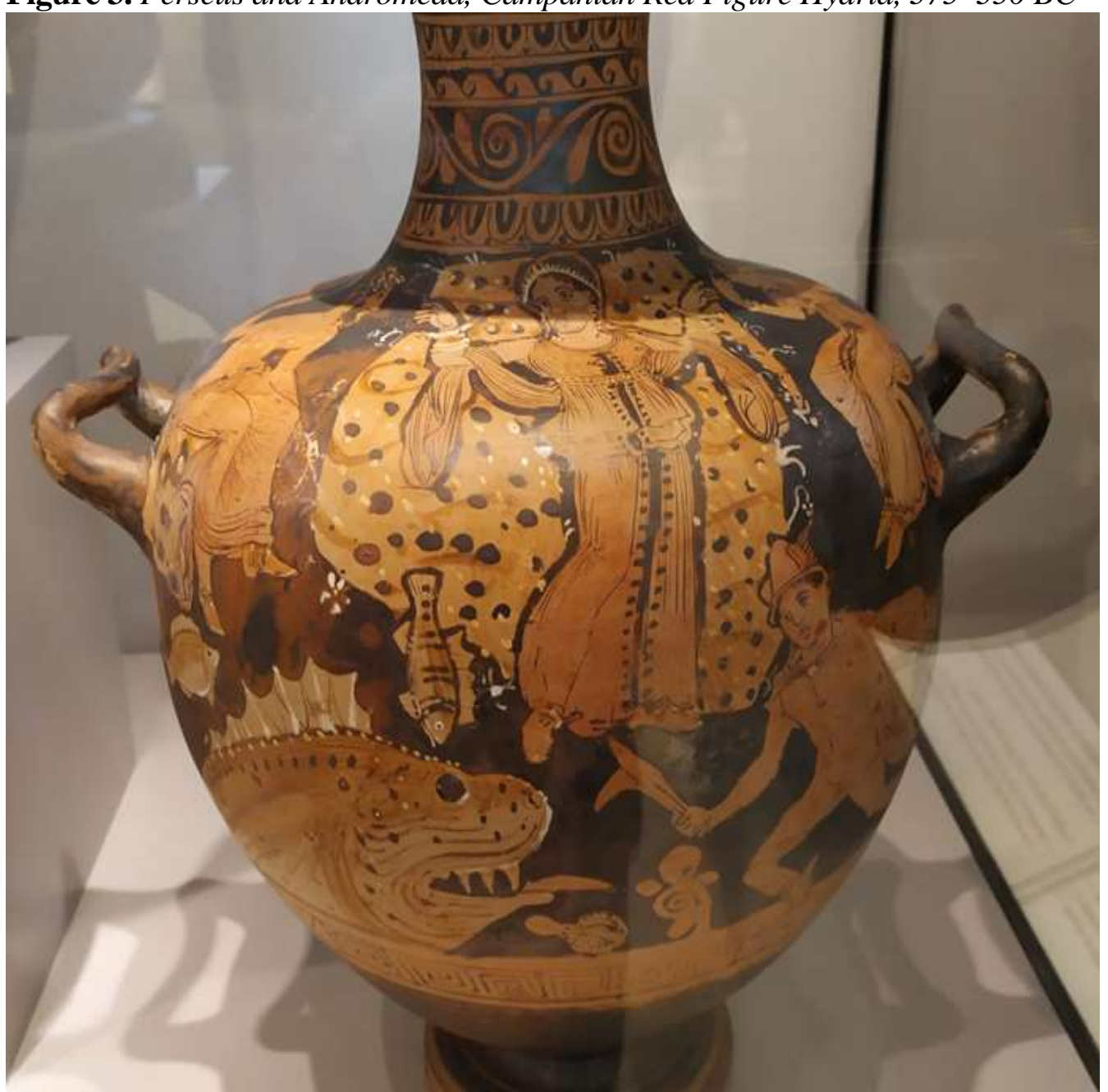

Source: Staatliche Museum, Berlin (No. 3238). Self-Obtained.

The cave is a symbol worth studying in more detail. Many myths connect dragons and caves, particularly situating dragons living in caves, as seen in descriptions of Drakon, the dragon Cadmos encountered, and Python, the dragon Apollo met. Caves are also considered the womb of a great mother goddess, such as Gaia or Eileithyia (Padel 1992, pp. 99-102, Parisinou 2000, pp. 45-48). The shift in Andromeda's representations from the locale of capital punishment to the 
cave's entrance stresses her feminine-fertility aspects, as well as her association with marginallocations between life and death, fertility and barrenness. Hence the paradigmatic alteration of the poles to the cave entrance suggest the theme of "the bride of death" by stressesing her liminal position in this particular timeframe (Dowden 1989) ${ }^{1}$.

These vases further emphasize issues of marriage and death through their images of a parade of gifts. Phillips contends that most of the vase paintings show items related to weddings and funerals. For example, included on the Attic pelike (see Figure 2) are a stool and a box, which are identified as gifts given at weddings, but also as funeral gifts for those who have died before marrying (Phillips 1968, pp. 4-7). Another figure repeatedly shown on these these vase paintings is Cepheus, the mourning father who alludes to Andromeda's approaching demise; Perseus asks Cepheus for his daughter's hand in marriage at the moment when her death approaches, connecting to "the bride of Hades/death" theme as well. Signs presented in images of Andromeda and signifying "the bride of death" theme are keys to understanding the meaning of her image as the liminal moment in which a maiden metamorphoses into a bride.

There is a significant amount of evidence of this myth that has been recovered, proving its popularity in the fifth and fourth century BC. The absence of the dragon in the scene is most striking, especially in light of the sixth-century BC Corinthian amphora (see Figure 1) that includes dragon-combat iconography. This omission highlights the meaning and function of the dragon when it reemerges.

The third type is the first to present a dragon, paradigmatically alternating the wedding/funeral gifts. A Campanian bell-crater, dated 375-350 BC (see Figure 4), is the first painting after the Corinthian vase to represent a dragon, though no combat takes place. The composition is artificial and static, and a register of sea waves separates the scene from the viewer, perhaps indicating a direct inspiration from a theater play.

\footnotetext{
${ }^{1}$ On the connection between marriage and death, see Jenkins (1983, p. 142), Seaford (1987), Barringer (1991). On the connection between Andromeda to the theme of "the bride of Hades," see Schmidt (1960, pp. 43-50), which contends this idea to be represented only in south Italy (Phillips 1968, p. 11, Keuls 1976, p. 451, pl. 7).
} 
Figure 4. Perseus and Andromeda, Campanian Red-Figure Bell-Crater, 375-350

$B C$

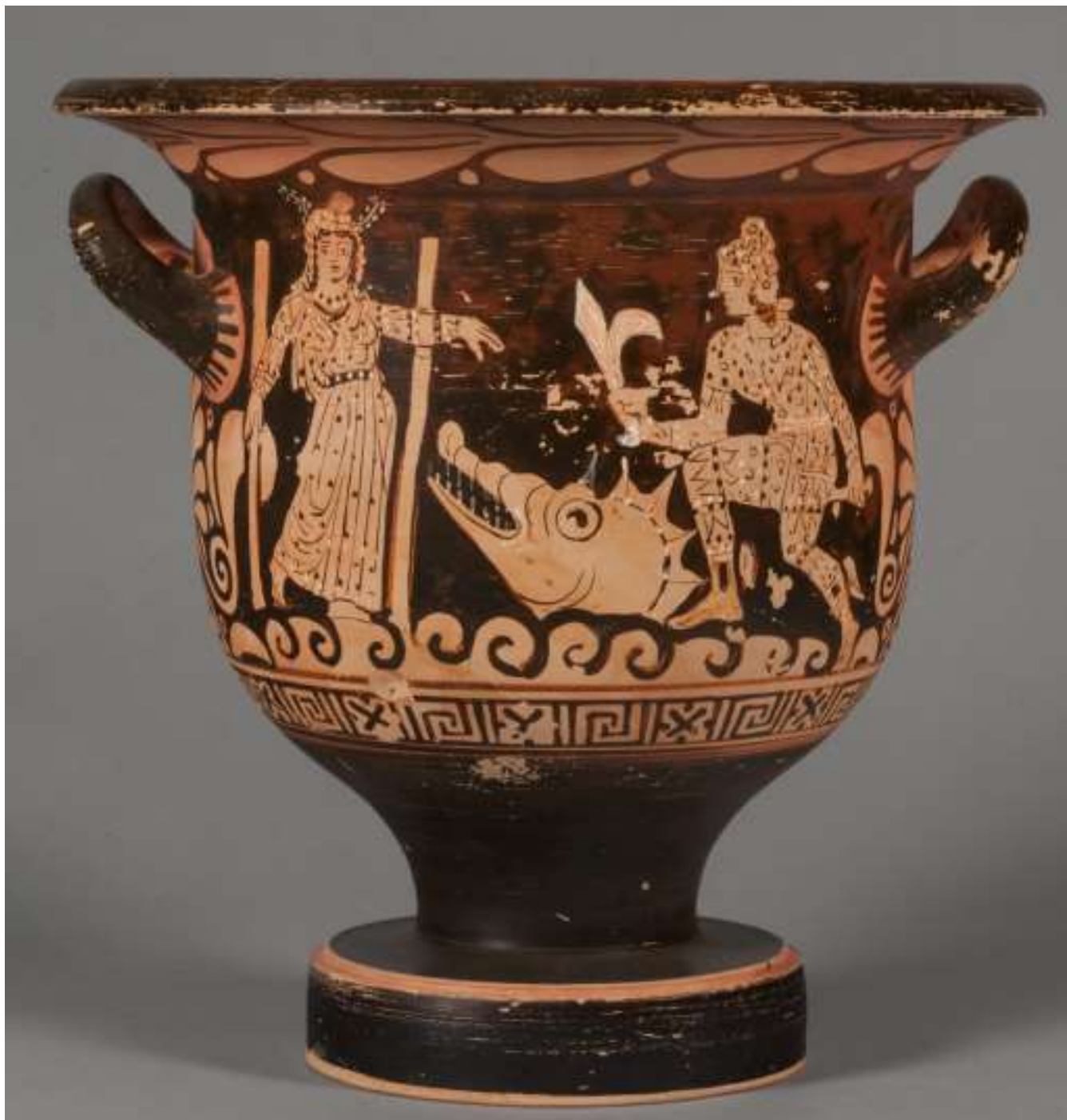

Source: James Logie Memorial Collection, University of Canterburg, Christchurch (41/57) (c) Photograph courtesy of the Teece Museum of Classical Antiquities, University of Canterbury, New Zealand. Photographer Duncan Shaw Brown.

The third type, manifested in several Apulian vases, represents the fight with the dragon, as seen on an loutrophoros by the Darius painter from about 330-340 $\mathrm{BC}$ (see Figure 5). The similarity of these vase paintings gives rise to the suspicion that a famous painting was their source (Phillips 1968, p. 10, D'Alconzo 2014, pp. 75-91). In this type, the wedding/funeral signs are paradigmatically replaced by a dragon, a more obvious sign for the "bride of death", which had matured by that point. 
Figure 5. Darius Painter, Perseus and Andromeda, Apulian Red-Figure Loutrophoros, 340-330 BC

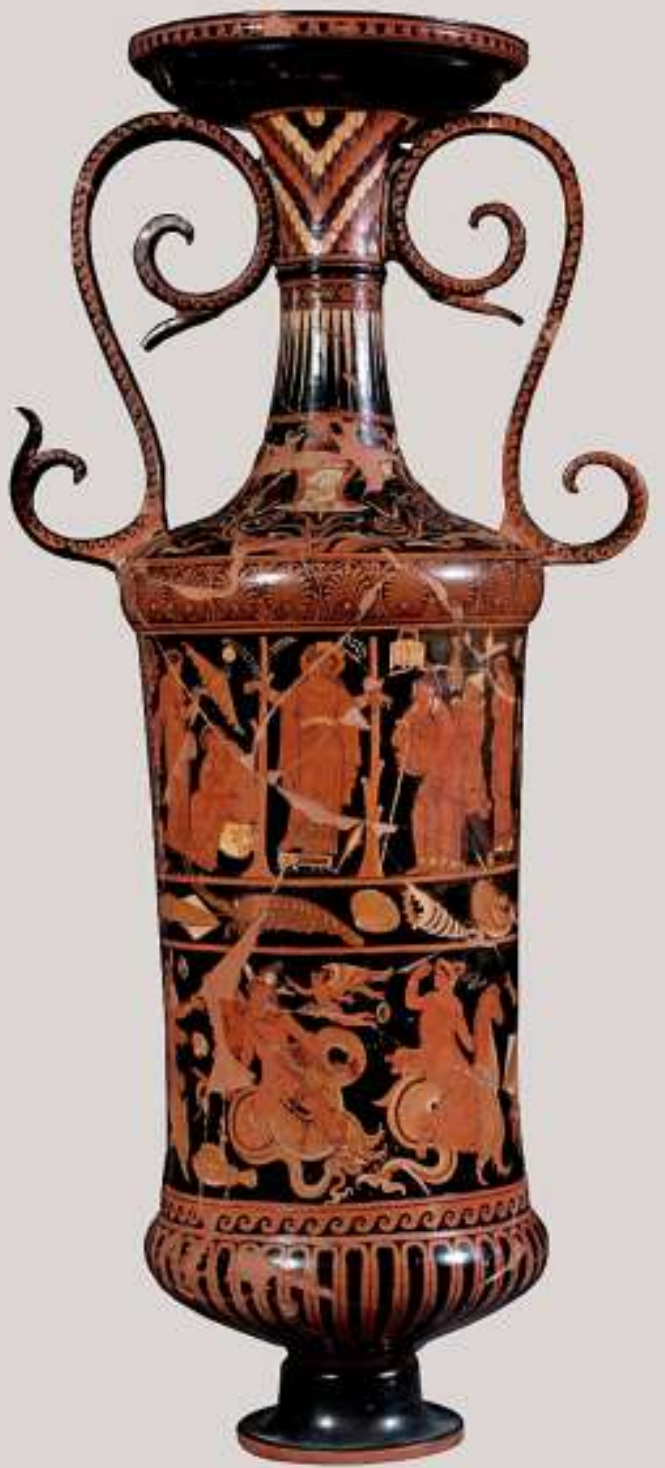

Source: $\odot$ su conncessione del Ministero per i Beni e le Attività Culturali e per il Turismo - Museo Archeologico Nazionale di Napoli - photo Di Giorgio Alban.

Phillips recognizes the painting on the Darius painter's loutrophoros (see Figure 5) as a case in which the vase itself is one of the wedding/funeral objects, connecting the object's function to its decoration. The sign of the dragon highlights Andromeda as "the bride of death" through another comparable issue in the myth: Andromeda is betrothed to Phineus, but this fate is revoked when she is put forth as a sacrifice to the monster; Phineus is unwilling or unable to fight the dragon and therefore an unworthy man. Only when she is promised to Perseus is she saved from death. 
The appearance of the dragon highlights the theme of "the bride of death". The liminal moment of the death of Andromeda as a maiden and her reemergence as a bride. This liminal social concept is symbolically portrayed by the threat of actual and metaphorical death perpetrated by the dragon, a symbol of the underworld kingdom. This theme is well described in Achilles Tatius's secondcentury AD ekphrasis (1961, p. 148-9: 3:7), which details an Andromeda painting by Evanthes at Mount Casius in the temple's Pelusium:

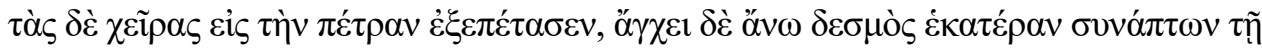

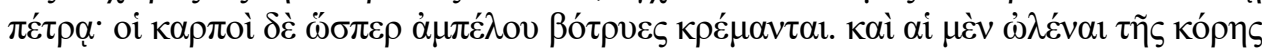

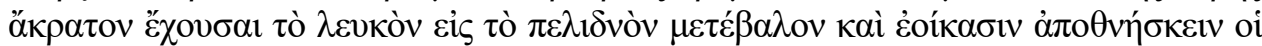

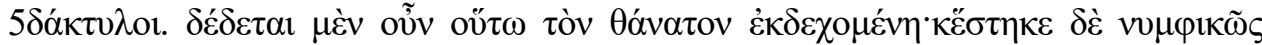

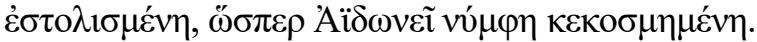

(Her [Andromeda's] hands were stretched out against the wall of rock, a bond holding both of them fast to it above her head, so that her fingers hung like bunches of fruit from a vine; the arms of spotless white verging towards the livid, and the fingers white with the pallor of death. Thus was she bound, waiting for her fate, adorned for a bridal as one who was to be the bride of the King of Death).

This ekphrasis vividly describes the contrasting events that befall Andromeda at the same moment in the narrative - she is a bride set to marry a hero or a dragon, whichever comes first. Achilles Tatius names the dragon "the King of Death", alluding to Hades.

By the middle to the end of the third century BC, depictions of Andromeda became the most popular, principally in southern Italy. Nicobule's documentation suggests that plays about Andromeda continued in Greek, stating that Alexander the Great recited Euripides's Andromeda from memory at his last dinner party. This documentation actually dates from almost five hundred years after Alexander's death, so the apocryphal incident might be nostalgic or outright fabricated. In the time between the early Hellenistic era and the first century, however, astronomical and historical writing commonly quotes the Andromeda plays by Sophocles and Euripides. There is evidence of Greek plays about Andromeda by Lycophron, Phrynichus, and Scylax; Latin writers such as Livius Anndronicus and Ennius also wrote several plays about her (Ribbeck 1892, vol. 1, p. 3: 30-32, vol. 2, pp. 8-9, Jacoby 1923, p. 127: fr. 2, Warmington 1967, vol. 1, fr. 136, vol. 2, pp. 254-261, Snell 1971-2004, vol. 1, p. 323: 212: T1, Apollodorus of Athens 2008: 2:4:3, Lucian of Samosata 2009, p. 24, Scylax 2011, pp. 44, 182: 104-GGM:79, Worthington 2012, p. 4, Eratosthenes of Cyrene 2013, pp. 15-17, 22, 36, Ogden 2008, pp. 7, 70-72, Ogden 2013b, pp. 162-177).

The Hellenistic era introduces the fourth type, in which Andromeda is chained to a chair, and Perseus moves forward with his foot atop an amphora from Bari, dated to 325-300 BC (LIMC 1981-1999, vol. 2/1-2, p. 777, figure 16). This might be the root of the iconography common in second- to fourth-century AD mosaics in which Perseus strides toward Andromeda and is usually stands on the body of Ketos (see Figure 6). In the Hellenistic type the dragon nonetheless vanishes again. 
Figure 6. Perseus and Andromeda, Mosaic from Bulla Regia, Third Century AD.

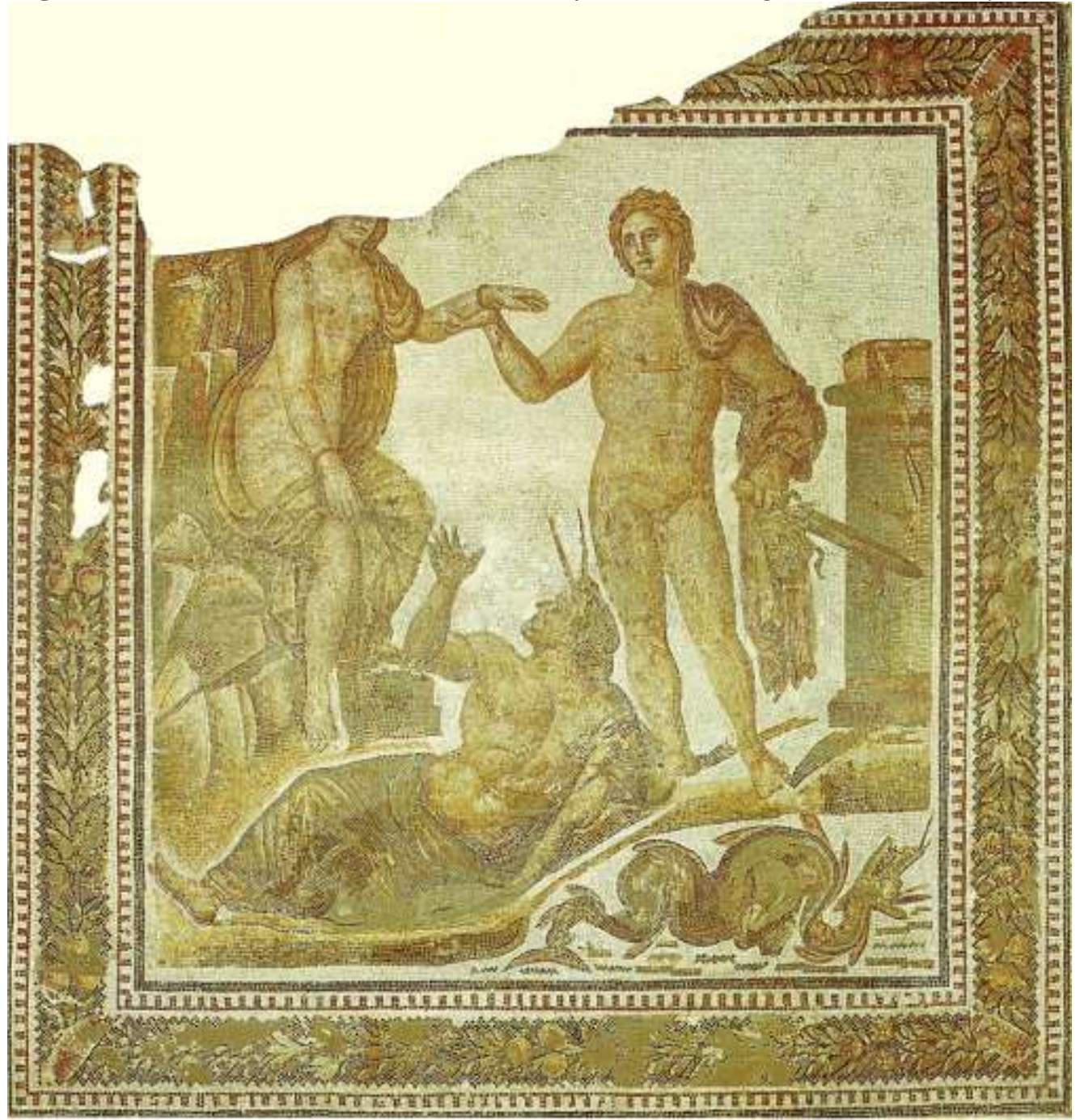

Source: Bardo National Museum. public-domain.

Despite fragmentary evidence, it can be assumed that the play of Andromeda was fairly popular during the Hellenistic and Roman Republican age, but the material evidence suggests a decline in the popularity of the myth. Instead great amounts of artistic evidence of the myth, contemporary to Ovid, are found at the remains of Pompeii, Herculaneum, and neighboring villages. 
Figure 7. Boscotrecase Painter, Perseus and Andromeda with Landscape, Fresco from the "Mythological Room" of the Villa-Agrippa Postumus, Boscotrecase, 11 $B C-2 A D$

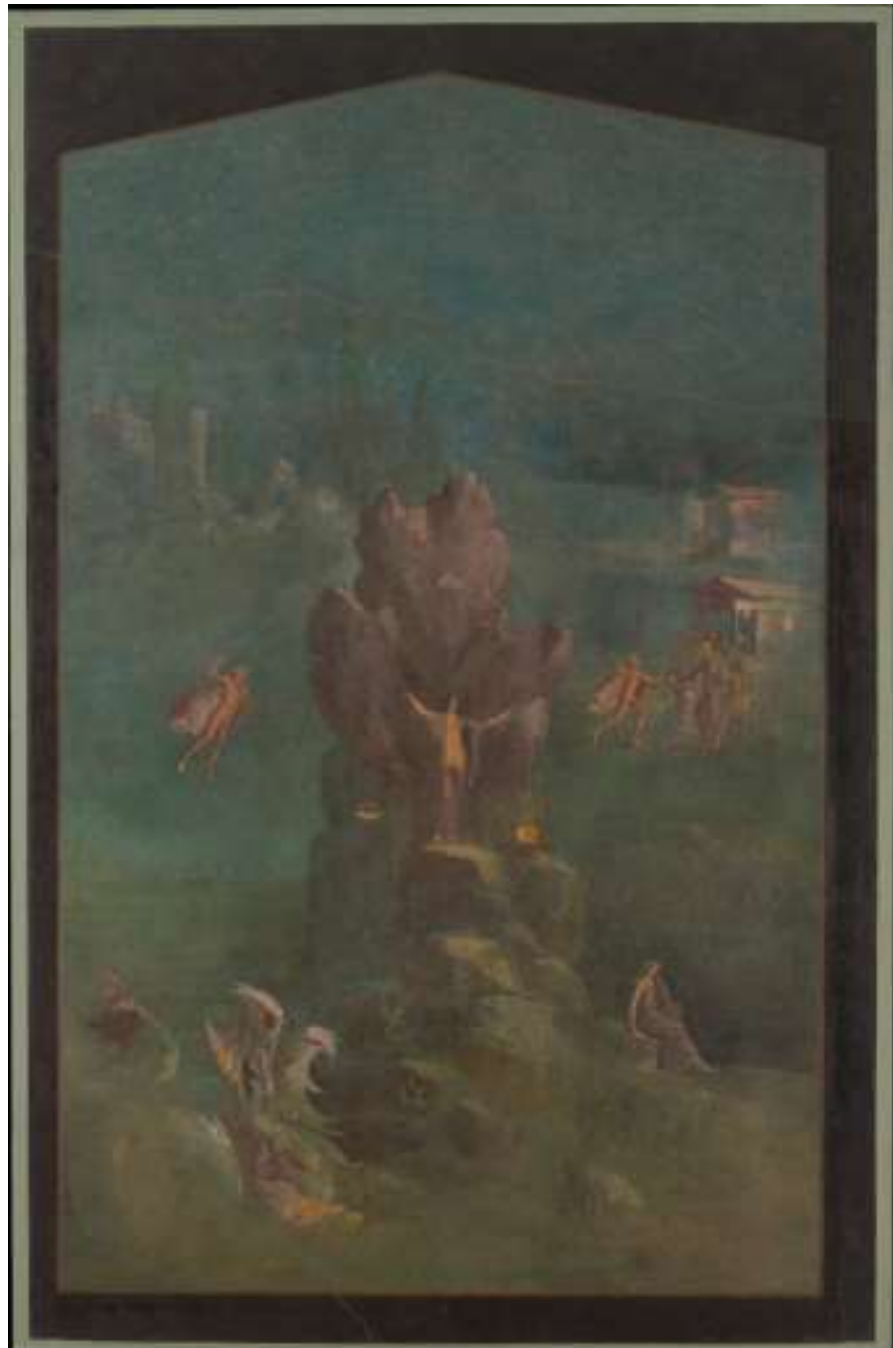

Source: Metropolitan Museum of Art, New York (20.192.16). (C Met: public-domain.

The most important and striking example of the Andromeda iconography from Pompeii and its environs is from the Villa Agrippa (see Figure 7), forming the fifth type (Von Blanckenhagen and Alexander 1962, 1990). Here Andromeda is bound to a rock that rises from the sea. Her arms are outstretched, and her silkylooking garment is draped over her arms, erotically hinting at her enticing curves. At her feet are wedding/funeral gifts, and on the rocky slope Cassiopeia sits grieving. On the opposite side a dragon emerges from the sea, its enormous head resembling a beautiful and exotic flower. Perseus appears twice in the composition, creating an intertwined narrative chronology. To the right of Andromeda, he emerges from the clouds in flight, sans Gorgon's head and brandishing his sword. $\mathrm{He}$ is also pictured to the right of Andromeda, shaking hands with her father. These elements of the depiction signal a continuity in the traditional iconography, combining the second and third types and also proving its continued relevance in 
first-century Rome. This is in spite of the complete lack of evidence of combat with the dragon in the Villa Agrippa painting. Perseus and the dragon appear on the same side of the composition, and the hero's sword is lifted high as if to attack, but they are too far away from each other to make a combat scene probable (Phillips 1968, p. 3).

The main themes of the Villa Agrippa painting are marriage and the erotic. Looking closely, the dragon clearly spits something from its mouth toward Andromeda - perhaps venom or acid. However, since the dragon resembles a flower, this detail immediately connotes sexual seed and an unfulfilled erotic encounter. Another painting from the same room, the Cyclops Polyphemus Courting the Nereid Galatea, stresses the recurrent theme of a monster's unfulfilled love of a maiden. Ketos is thus a central figure in this motif that presents the dragon's unattained aspiration to unite with the young woman.

The importance of the Villa Agrippa's painting rests in its patronage, the house of Agrippa (Marcus Vipsanius Agrippa, 64/62-2 BC). Agrippa was the closest friend and right hand of the Roman emperor Augustus (Imperator Caesar Divi Filius Augustus, September 23, 63 BC-August 19, AD 14) and was married to Augustus's daughter Julia Augusta (Julia the Elder, October 30, 39 BC-AD 14). Evidence suggests that the imperial princess designed and ordered these specific paintings for her resort house, so why did she choose this myth and these scenes? All other Andromeda paintings in Pompeii and its surroundings bear striking resemblance to the Agrippa paintings. An increasing interest in Andromeda may have also resulted in her myth's appearance in the imperial lounge.

This section could not possibly examine the socio-cultural and political context of all images; instead uses the beginning of the Imperial Roman era to elaborate this aspect. When the Villa Agrippa Andromeda fresco was made, the issue of marriage and fertility among the noble class was a central political issue, because of two problems that collided at the same time. There were not enough noblemen to lead armies due to numerous deaths among the elite of Rome. Meanwhile the power and liberty of elite matrons arose to great heights, allowing them certain liberties, including sexual ones, that were controversial (an understatement) in the patriarchal environment of that time. This led Augustus to disseminate propaganda that underscored the fertility role of women and the importance of marrying within one's rank, which required elite men to marry elite women, not lower-ranked or even non-citizen women. ${ }^{2}$ Julia Augusta finds herself at the center of this turbulence, accused of sexual promiscuity by her own father and sentenced to exile (Cassius Dio 2015: 55:10, Suetonius 1998, vol. 1, pp. 224 249: 2:65). This essay purports that the reemerging theme of Andromeda, accompanied by both the dragon and wedding funeral gifts, reflects this urgent social debate and Augustus's propaganda related to the values of rightful and traditional marriage.

This era in Pompeii also introduces a sixth iconographical type, which continued until Late Antique, an example of which is the fresco from the House of the Dioscuri (see Figure 8). Andromeda and Perseus are large central figures:

${ }^{2}$ For more information about Augustus's propaganda regarding the fertility role of women, see Gardner (1986), Milnor (2005), Dillon and James (2015, pp. 96-106, 372-84). 
Andromeda is on the cusp of being liberated, and Perseus is chivalrously helping her step down from the rock to which she was bound - the moment of joining hands, physically and metaphorically. Andromeda is partly naked, sometimes exposed as if by mistake; Ketos is presented as dead or as a neutered icon. Overall the composition presents the celestial constellation of Perseus, Andromeda, and Ketos. Phillips contends these are copies of a Hellenistic third-century painting by Euanthes (who was possibly from Tarentum), now lost, which was originally located in an Egyptian temple in Alexandria. He bolsters his claims with medieval astronomy books that depict a composition very much like the lost painting. Phillips conclusions as to the astronomical connotation of these paintings seem to be justified, but this analysis does not agree with his methods. He connects Pompeiian iconographical types and the Campanian red-figured hydria, but, in this study the two Pompeiian types seem disparate. This is especially apparent by comparing the intimacy of the couple with the distance between them in the Villa Agrippa type; the activity of the lifelike, as opposed to dead or neutered iconic Ketos; Andromeda's arms held out to the side versus gently holding Perseus; and the size of the figures. All these differences stress the distinctiveness of the two types (LIMC 1981-1999, vol. 2/1-2, figs. 35, 53, pp. 67-72, Phillips 1968, p. 3).

Figure 8. Perseus and Andromeda, Fresco from the House of the Dioscuri, Pompeii, 2-25 AD

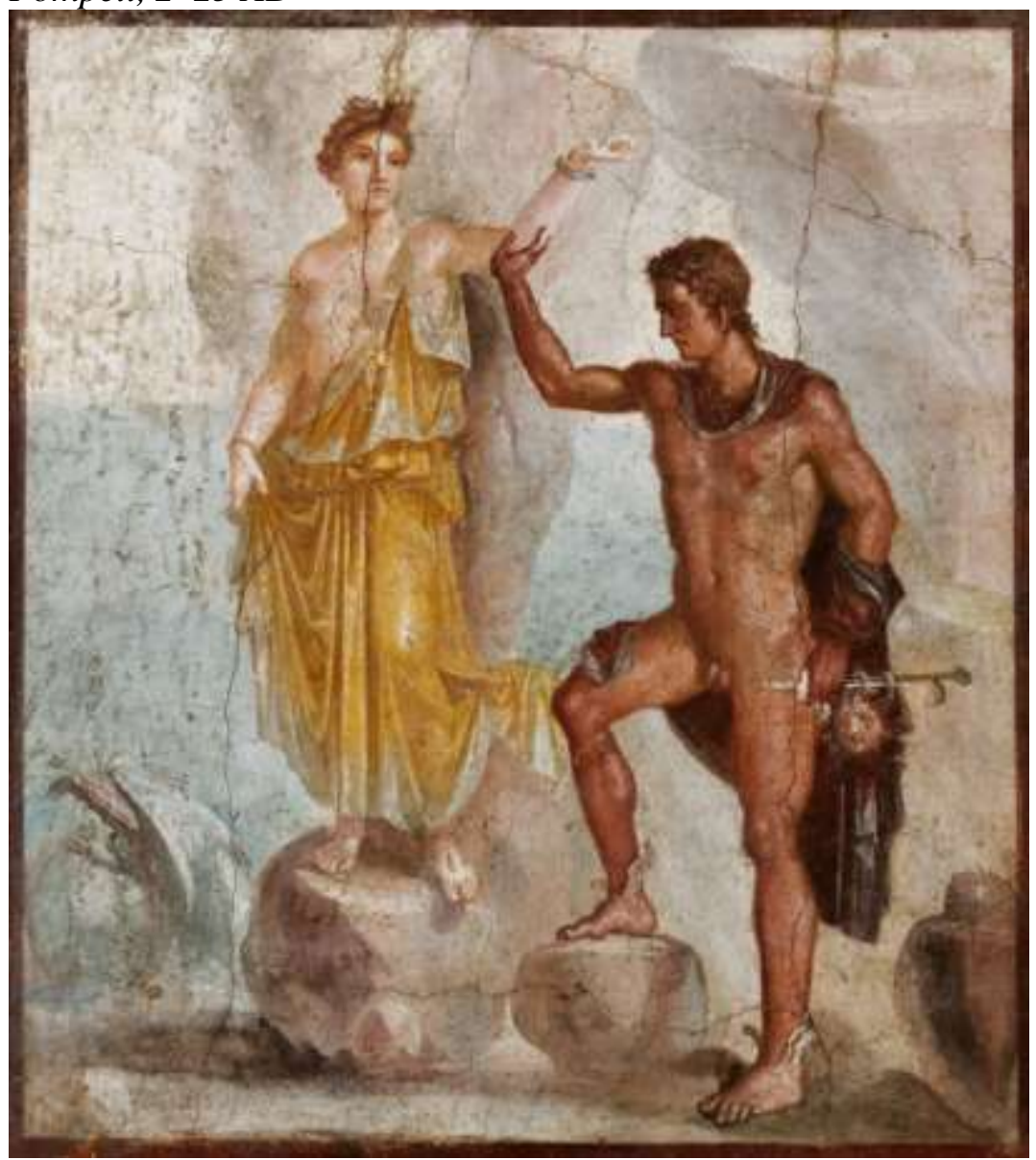

Source: National Museum, Naples (8998), public-domain. 
The previously discussed Augustinian propaganda must have been a reaction to the loosening of traditions and existing conventions, as supported by the simultaneou emergence of two opposite types. The Villa Agrippa type represents the propaganda's call to return to older traditions and to socially appropriate values, while the intimate connection between Perseus and Andromeda minimizes all marriage symbols - the gifts, Cepheus, and the dragon-to stress the increasing value of the collaborating couple and accentuating the importance of the woman in the marital union.

Moving chronologically toward the second century AD, many Andromeda floor mosaics of the sixth type are preserved, such as one from Bulla Regia (see Figure 6). Other items, including sarcophagi, games, bronze plates, and reliefs depict this myth as well. These objects gradually present the couple more intimately, seated side by side, which continues the fourth iconographic Hellenistic type.

The iconographic changes of the scene lead to realizations about the myth in different cultures and eras. The narrative and the choice of the moment represented underwent transformations: from a human scene to godlike beings, from a family event to a tête-à-tête. The scene that is depicted in the floor mosaics is astrological, both private and cosmological at the same time: this intimate scene is written in the stars.

The Andromeda myth mostly deals with the theme of marriage - "the good wife" for Greece's greatest hero, the most spoiled by the gods, is as passive as can be. Tied to her fate, Andromeda is a "bride of death". In other words, Andromeda is doomed to be united with the dragon unless a male hero comes to liberate her from this fate. The dragon represents the liminal moment when a maiden is transformed into a bride and is the emblem of the death of a girl's identity during marriage rituals, as she is reborn in her husband's paterfamilias. Before the sixth type, the iconographic emphasis is on Perseus asking permission from Andromeda's father for her hand in marriage, the proper way to gain a good, legitimate wife (Demand 1994, Lovén and Strömberg 2010). The sign of the dragon is determined by its function in artistic representations. It is obvious that the dragon was part of the myth at an earlier time, yet all but one of the artistic depictions do not present the dragon, nor the dragon-slayer topos until the middle of the fourth century BC. The main focus of Attic representations is Andromeda as "the bride of death" and Perseus asking her father for her hand. The moment the dragon emerges, all the wedding/funeral gifts vanish - a paradigmatic alteration. Thus the dragon must have something to do with marriage or union with the female protagonist, a role that will be revealed through analysis of the figure of Medusa.

To sum up, Andromeda is an example of the first type of "the woman and the dragon" motif, i.e., "the good woman" type. Her relationship with the dragon, according to a masculine point of view, is a threat - if the male figure does not come to save her she will surely perish. On the other hand, the dragon desires her, and if she is united with the dragon, a sacred union will take place that will lead to her to obtain knowledge of the godly sphere; "the good woman" has to be close to and then saved from the dragon-a married woman has to be separated from her 
power and identity. The Andromeda myth has an immediate comparison in its other half: the myth of Perseus and Medusa.

\section{Medusa}

The myth and images of Medusa have been highly prevalent and influential from ancient times through the present and are frequently examined in academic studies $^{3}$. This article presents the basic outline of the myth and the changing images of Medusa, contending that Medusa should not be approached as a monster alone - a drakaina (female dragon) — but as a woman that has been fused with the dragon. As such, she stands for a woman that was too dangerous to exist in GrecoRoman cultural context, so she necessitated control and containment. Separating Medusa's female and drakaina aspects illuminates the meaning and function of her image in the context of different patriarchal cultures. Several categories emerge: the ugly versus the beautiful Medusa and the head emblem versus narrative representations. By demonstrating the reasons that Medusa and Andromeda were fused in the myth of Perseus and comparing the two myths a main theme emerges: the delineation of a "good" versus a "bad" woman.

The Medusa myth begins with King Polydectes wishing to marry Perseus's mother Danae - a union to which Perseus objected, with legitimate right. Polydectes wants to eliminate Perseus, so he devises a plot in which Perseus cannot help but participate. Polydectes invites all his subjects to his palace, requesting that each bring a horse as a gift. Without a family estate, Perseus cannot fulfill the king's request. For Perseus to redeem himself, according to Polydectes, he must obtain the head of the mortal Gorgon Medusa, a hopeless and fatal task as her gaze can turn the living to stone. Perseus, as the son of Zeus, is granted assistance from the gods to prevail: a shield and some advice from Athena, winged hat and sandals from Hermes, a sword (herpa) from Hephaestus, and a garment of invisibility and a special bag (kibisis) from Hades. These gifts were granted to him by the Nymphs, probably the Hesperides, considered by the scholia of Apollonius to be sisters of the Gorgons and the Graeae (Apollonius of Athens 2008, pp. 12-13: 2:4:2, Wilk 2000, p. 21, Ogden 2013a, p. 98). Perseus's first objective is to find Medusa, whose location is known only to the Garaiae sisters. The Graeae share one eye and one tooth, which Perseus (with the guidance of Hermes) steals and uses to ascertain the location of the Gorgons: a cave on the margin between the world of the dead and the living. Medusa is the sole Gorgon out of three who is mortal; the sisters' deadly gaze is their weapon and curse, forcing them to remain eternally isolated. Perseus enters the cave, using the reflection from Athena's shield to see his adversaries yet avoid their deadly gaze, and decapitates the sleeping Medusa. The specifics in this part of the story vary. Sometimes Perseus's hand is guided by Athena or Hermes. The narrative frequently emphasizes that Perseus does not have to worry that he will not to be able to slay Medusa - there is no fight and almost no danger. Since Medusa has no chance to fight back, his act is

\footnotetext{
${ }^{3}$ Wilk goes to the lengths of presenting the global appearance of Medusa from ancient until modern times and proves how global this image is; see Wilk (2000, pp. 55-85, 193-224).
} 
neither honorable nor analogous to dragon slaying. Perseus then flees her enraged Gorgons sisters, Stheno and Euryale, the moment the Andromeda myth begins. After Medusa is decapitated, the fully grown Chrysaor and Pegasus emerge from her body (Gantz 1996, vol. 1, pp. 304-7, Garber and Vickers 2003, pp. 25-41, Ogden 2013b, pp. 82-96, Ogden 2013a, pp. 92-104.).

The main question is who or what is Medusa? This question expands in light of the extremely uncommon frontal image of Medusa, as opposed to the profile view most commonly used in Greek art. Evidence supports that Medusa appeared before the Indo-European invaders arrived in the Peloponnese in the tenth century BC. Some credibly connect her to the image of Humbaba, the monster Gilgamesh and Enkidu encounter (Pritchard 1969, p. 79), and masks presumably in her image have been found. Her accepted origins are also "lion masks" from the ninth and eight centuries BC found at Tiryns and those dated to the seventh and fifth centuries BC at Sparta, and Bas, the Egyptian fertility midget-god image (Carter 1987, Frontisi-Ducroux 1995, Wilk 2000, pp. 31-32, 36, 62-65, Tefnin 2003, pp. 65-108, Ogden 2008, p. 35, Dexter 2010 pp. 32-36, Ogden 2013a, p. 95).

Medusa is assumed to have been a goddess that functioned as a great mother divinity, worshipped by Minoan and other matriarchal cultures of the Peloponnese. In her article "Medusa and the Female Gaze", Susan R. Bowers reviews the feminist and gender aspects of the image and function of Medusa in Greco-Roman cultures. Feminist scholars have concluded that "the Greco-Roman Medusa . . . is actually a perversion of a matrifocal culture's goddess", seeing her as a Black Libyan Amazon, a residue of a goddess of matriarchal cultures, or magna mater (high mother goddess). "Medusa was obviously more than a mother goddess", Bowers contends, "perhaps originally both the giver of life and death, and the giver of rebirth and immortality" (Culpepper 1986, pp. 22-24, Burkert 1988, pp. 26-30, Bowers 1990, pp. 217-35 [quotation pp. 217, 220], Wilk 2000, 25, Dexter 2010, pp. 25-41, Ogden 2013a, pp. 91: 61, 95).

Ogden follows Burkert in identifying Medusa's origin in the Mesopotamian Lamashtu figure, which developed into the Greek Lamia monster, the devourer of children (Ogden 2013a, pp. 91: 61, 95). Feminist scholars contend that the Medusa myth is an allegorical interpretation of historical events from the Indo-European patriarchal invasion of matriarchal cultures, as documented in Pindar's fifth-

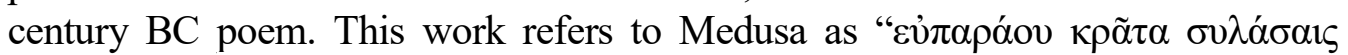

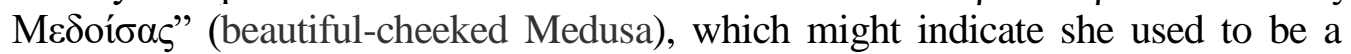
beautiful woman and laments her brutal killing by Perseus (Pindar 1997, pp. 39293: $12: 14-15)^{4}$. Pausanias documents a tale he heard while traveling in the market square of Argos in the second century BC, which detailed that the head of Medusa was buried there and asserted that she was an African queen (Pausanias 1979, pp. 180-181:2:21:6). Diodorus Siculus, who probably followed Dionysius Skytobrachion's tradition, documented in the first century BC a story of the Gorgons as warrior-queens in Africa that had defeated another Amazon tribe but were overthrown by Perseus during Medusa's rule (Jacoby 1923, p. 32: F7; Diodorus Siculus 1700, pp. 70-71, 54-55: 3:52). Hence Medusa's origins are

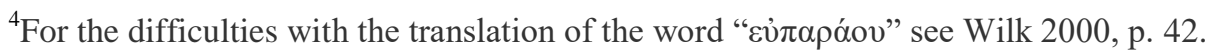


assumed to be a powerful woman who was decapitated, and her head functioned as a powerful symbol for centuries.

In his 1896 text, Roscher divides Medusa's images into a typology that is still valid today (Roscher 1896). Roscher's first type is the Archaic Medusa, best exemplified by her image on the pediment of the Temple of Artemis at Corcyra on Corfu, dated to the early sixth century BC (see Figure 9). Her round face is depicted frontally with huge eyes and nose, a swollen tongue that protrudes from her mouth, boar's teeth, curly hair, and snakes on her shoulders and belt. This frightening appearance was meant to protect the temple according to the principles of apotropaic (apotropaios) — guardian or protector - images, the root of Medusa's images. The word apotropaios is translated from Greek as "to turn away" (Wilk 2000, pp. 31-42). Consequently there is an overwhelming amount of Medusa images on temples, shields, and armors, statues of Athena, vase handles, coins, and magical amulets, among other objects (Hesiod 2018b, pp. 24-27: 270-94). Perseus does not appear on the relief from the Temple of Artemis so it is nonnarrative. Nonetheless, Medusa is positioned in her typical kneeling-running position, which alludes to the narrative, as if she is trying to escape her fate.

Figure 9. Medusa with Chrysaor (and Pegasus) with Two Lions, Pediment of the Temple of Artemis at Corcyra on Corfu, Early Sixth Century BC

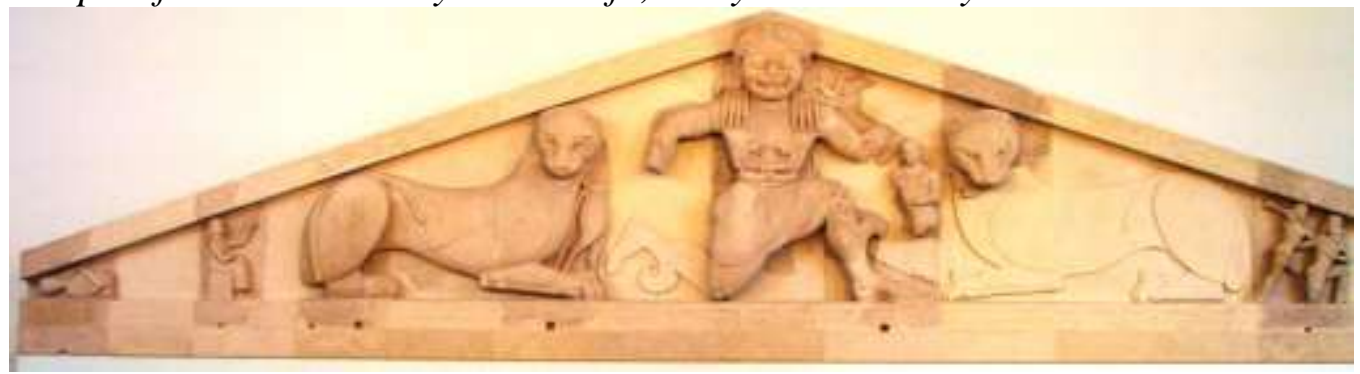

Source: Archaeological Museum of Corfu. public-domain.

The myth of Perseus and Medusa is first evident in the sixth century BC work by Hesiod, Theogony, which describes Poseidon and Medusa's gentle and passionate sexual intercourse. But this myth evidently originated much earlier, as suggested by a proto-Attic amphora from the second quarter of the seventh century BC (see Figure 10) presents Perseus's flight from Medusa's sisters. This is one of the earliest depictions of Gorgons with snakes coming out of their shoulders and worn as belts, connecting Gorgons to the topos of the dragon. Ogden gathers documents that mention Medusa as a drakaina, but, even from this early stage when Medusa is still in her ugly form, sometimes even bearded, it is clear that she is a human female, a woman monstrous image. 
Figure 10. Polyphemos Painter, Perseus Flees from the Gorgons, Proto-Attic Amphora from the West Cemetery at Eleusis, 675-650 BC

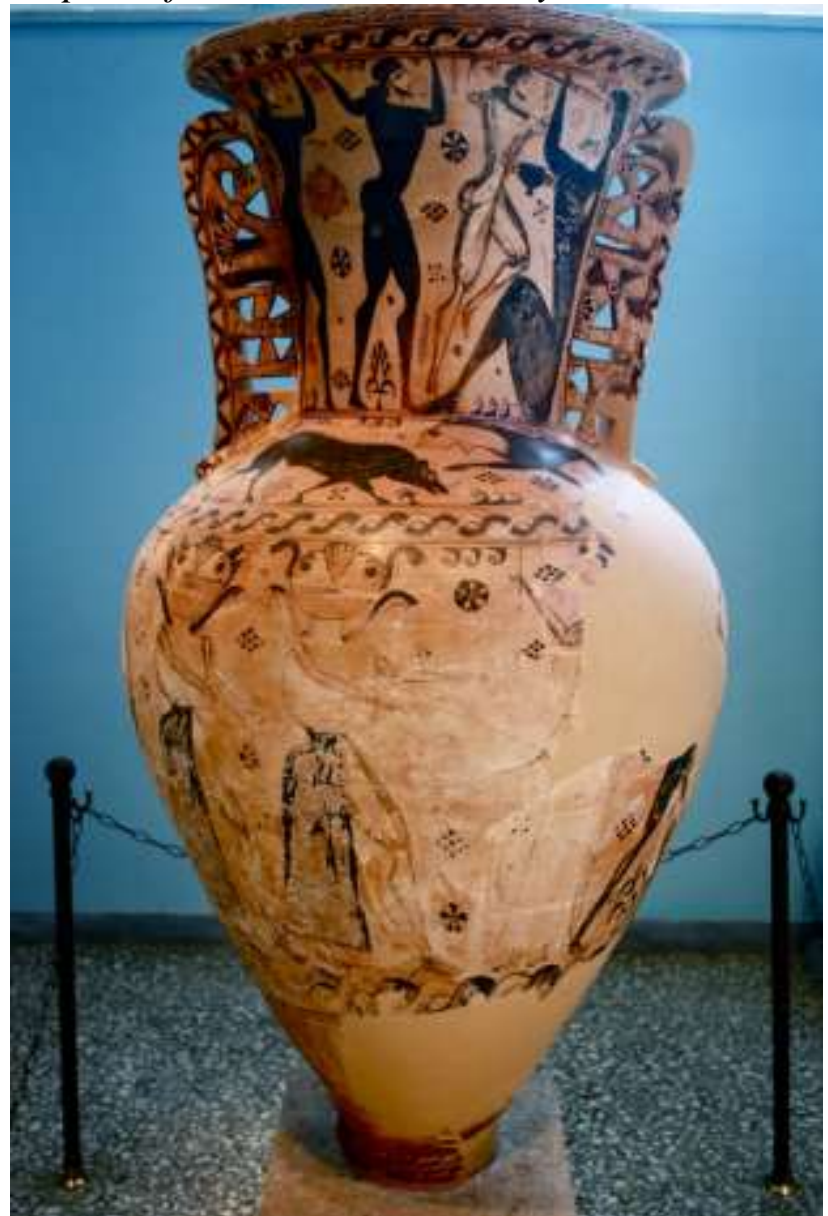

Source: Eleusis Archaeological Museum (2630). public-domain.

From the same period are narrative depictions, in which Medusa is sometimes shown as slain by Perseus with Hermes, as in the Attic olpe (jug) by Amasis (see Figure 11), or with the assistance of Athena, as seen in a metope on Temple $\mathrm{C}$ at Silenus (see Figure 12). Perseus's overwhelming assistance from the gods is mentioned in the literary sources, but gets amplified in artistic representations (LIMC 1981-1999, vol. 4/1, pp. 285-330, vol. 4/2, pp. 163-221, Renan 2001, pp. 71-84). This issue is central for this argument: the assistance Perseus receives may be because of his family relationship to these gods, but it may also be, and is emphasized in art as, a higher power leading the hand of the hero, the means through which faith is expressed. The gods have to ensure that this grotesque hybrid monster is beheaded. 
Figure 11. Amasis Painter, Perseus Slaying Medusa with Hermes, Attic BlackFigure Olpe, 550-530 BC

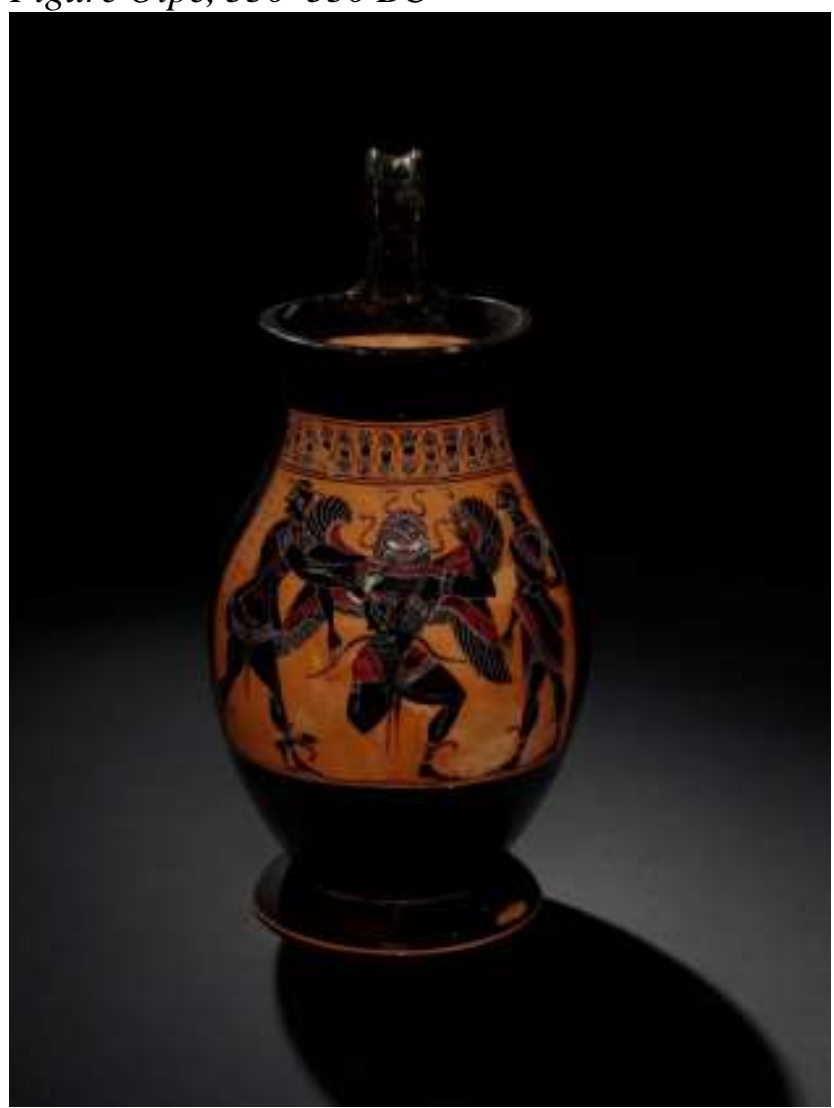

Source: British Museum, London. ( British Museum.

Figure 12. Perseus Decapitating Medusa with Athena, Limestone Metope from Temple C (for Apollo) at Silenus, c. 550 BC

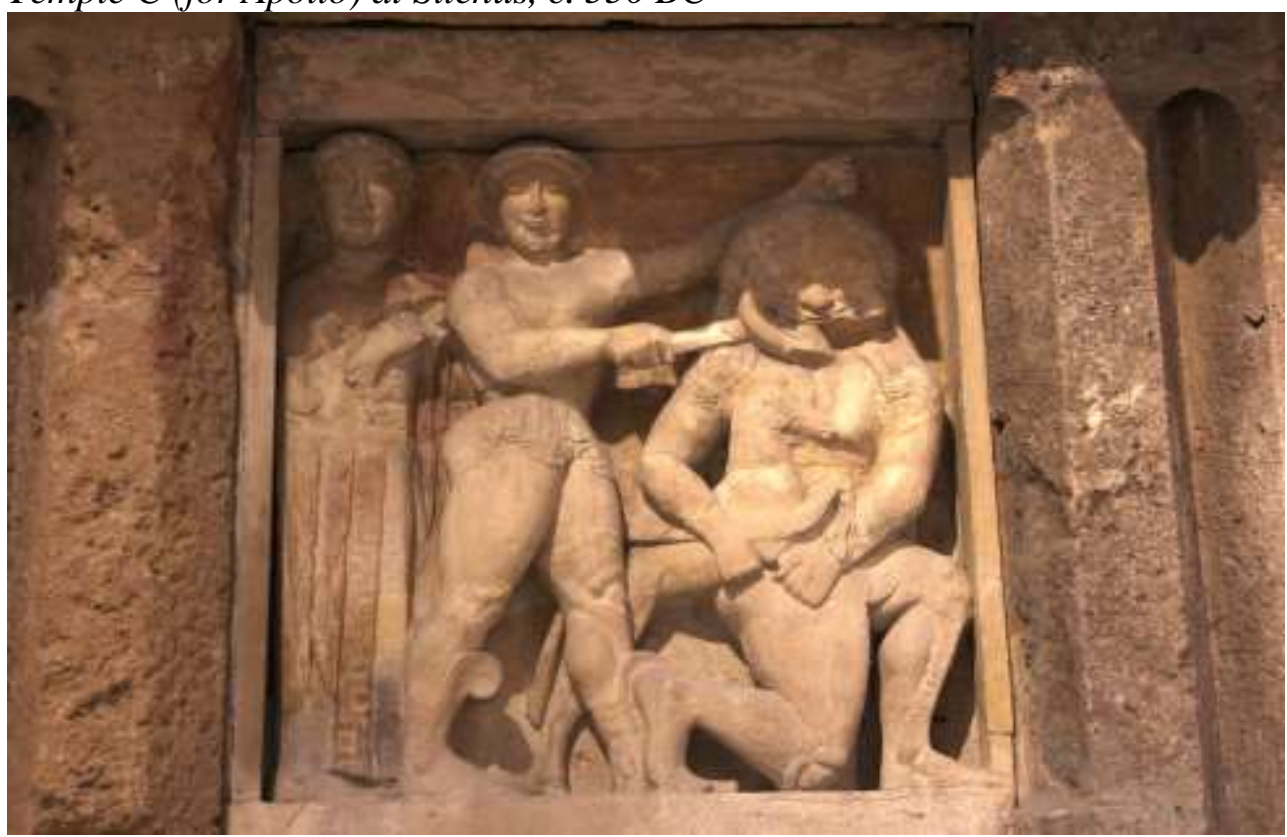

Source: National Archaeological Museum, Palermo. public-domain. 
At the beginning of the fifth century BC-the age of Pindar-Medusa's artistic representation is transformed into a beauty. The first beautiful Medusa is considered to be the head of Medusa that decorated the shield of Phidias's Athena Parthenos statue in Athens's Acropolis, referred to as the "Medusa Rondanini" (see Figure 13). From that point onward, Medusa was depicted as both grotesque and beautiful and her hair of snakes becomes her attribute (Pindar 1997, p. 293: 10:46-48, Buschor 1958; Harrison 1977, pp. 162-175, Belson 1980, pp. 373-378).

Figure 13. Phidias, Medusa Rondanini, Marble Roman Copy of the Bronze Gorgon's Head that Decorated the Shield of Athena Parthenos Statue on the Acropolis of Athens, 500-475 BC

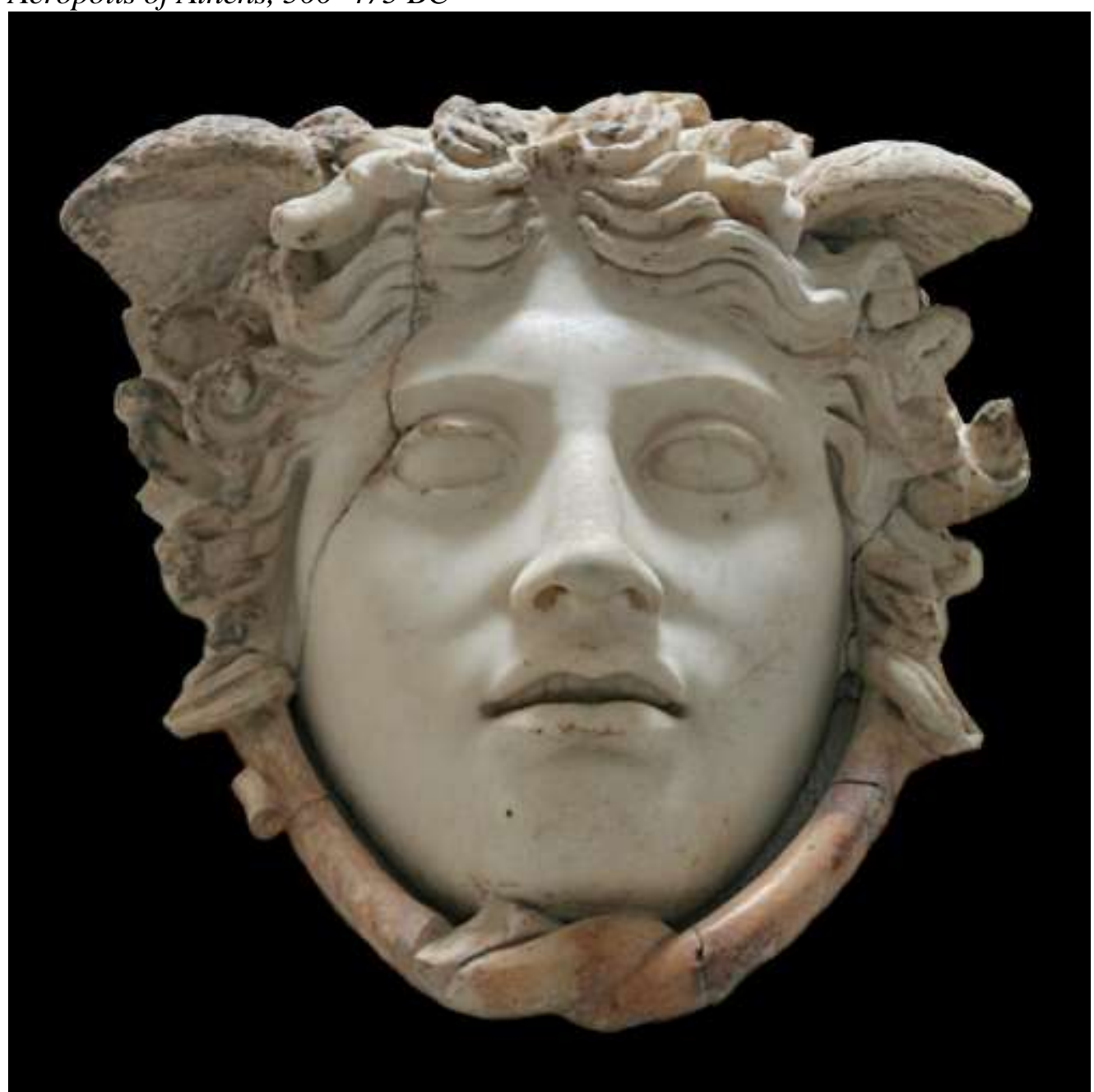

Source: Glyptothek, Munich (252). public-domain.

Although the artistic evidence presents Medusa as beautiful only starting in the fifth century, Daniel Gershenson claims Medusa was always perceived as both grotesque and comely, even in Indo-European literature. Dexter emphasizes Poseidon's attraction to Medusa in Hesiod's account. Therefore the case is a paradox: Medusa is a dragon, but also an anthropomorphic female. Ovid is the first to specifically narrate Medusa's metamorphosis from beautiful to grotesque, 
which may have roots in earlier times and is not just the author's will to justify an artistic phenomenon. Nonetheless, this artistic shift highlights the moment in history when Medusa was conceptualized as both horrific and erotic at the same time (Ovid 1998: 4:793-803, Gershenson 1989, pp. 373-90, Dexter 2010, p. 27).

Medusa originated as a beautiful girl according to Ovid, who particularly emphasizes her gorgeous hair. She was Athena's priestess and sworn to chastity. Poseidon is taken by her beauty and rapes her in the Temple of Athena. Athena, as punishment for her defiled sanctity, punishes Medusa by making her grotesque. The goddess transforms Medusa's beautiful hair into venomous snakes and makes her gaze turn the living into stone. This story encapsulates many issues: the origin of Medusa as a beautiful maiden, hair as a symbol, and ancient concepts of rape, Athena, and chastity. The tale also cautions of the danger of nonvirgins encountering sacred snakes (Ogden 2013a, p. 203).

Ovid's anthropomorphized description of Medusa is evident in art from an earlier time, such as on Polygnotos's Attic pelike of the fifth century BC (see Figure 14), which portrays Medusa as a human with wings who can only be identified as the mortal Gorgon because of Perseus. Perseus holds Medusa by her hair, a typical pose of victimization (Topper 2007). Polygnotos paints Medusa as a victimized woman, bringing the viewer closer emotionally to her tragedy and stressing that Medusa was perceived as a woman first and a drakaina second.

Figure 14. Polygnotos, Perseus, Medusa, and Athena, Attic Red-Figure Pelike, $450-440 B C$

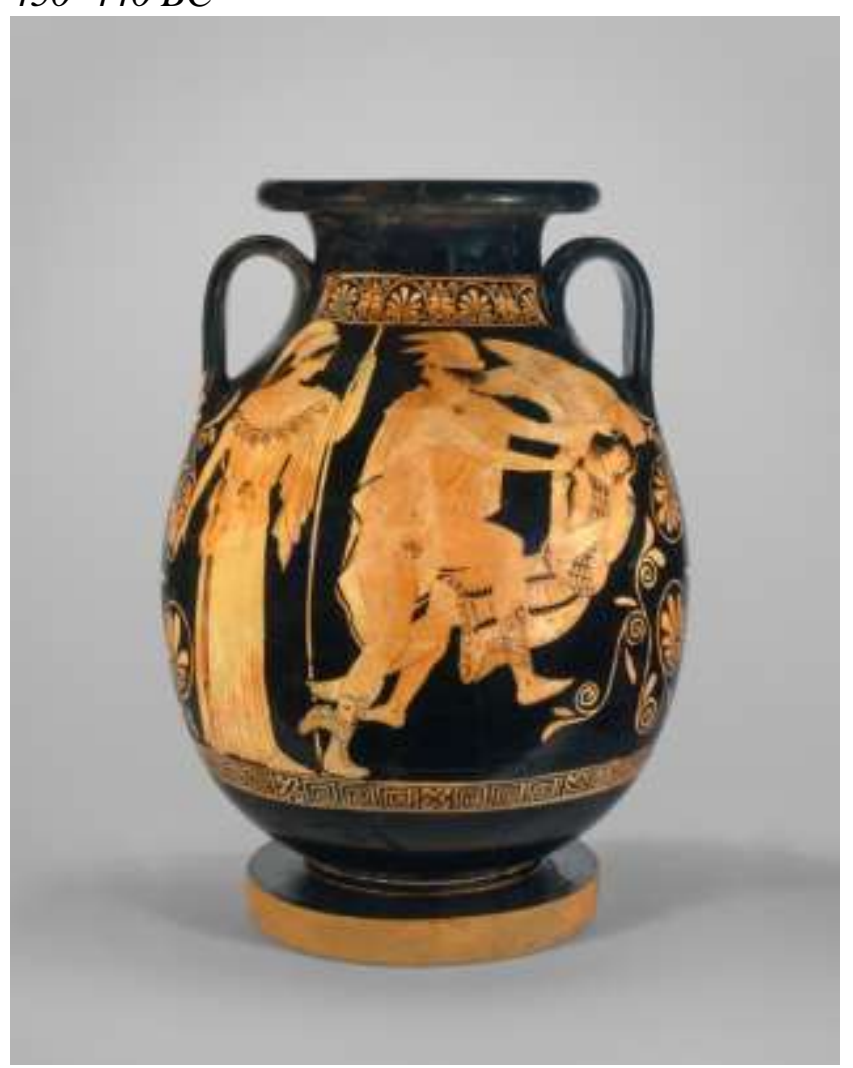

Source: Metropolitan Museum of Art, New York (45.11.1). (C Met: public-domain. 
Peculiarly, in comparison with the enormous amount of evidence of Medusa's head, only a few images depict the mythical narrative. In the fifth and fourth centuries BC, most narrated paintings present the moment after Medusa is decapitated. Polygnotos's iconography is rare, but other examples do exist, and depicts Perseus as sometimes guarded by Athena and Hermes as he slays Medusa. Overall these representations suggest divine assurance of her successful slaughter and her iconic head as a reflection of the fear of Medusa's image-Medusa must die!

Looking only at the basic theme of the myth, neglects Medusa's contradictions that are present in the artistic evidence. These opposing tendencies explicitly do not allow her to exist within Greco-Roman patriarchal culture and so the concept she represents must be exiled and eradicated. She is a woman that has both sacred knowledge - accessible only to virgins-yet she has been defiled, so she emblematizes the idea of the "holy-defiled." Her knowledge of the two worlds makes her unbelievably strong: with only a look she can kill, even after her death, and her blood can heal and create life, but also take it (Mayerson 1971, pp. 131132). Her influence extends to everything that comes in contact with her, even postmortem, and her female essence is seductive. Emphasizing Medusa as not entirely monstrous, but a beauty that metamorphosed into a grotesque being, or more accurately, was fused with a dragon, makes her petrifying, sacred and defiled at the same time.

Documents testify to the evils that might transpire if a virgin who has gone astray performs holy acts, such as in Pausanias's story of a priestess of Artemis who is sworn to virginity but hosts her lover in the Temple of Artemis. This so angers the goddess that she inflicted plagues on the city until both priestess and lover were sacrificed to her. Another example is the Lanuvium ceremony in which, if the woman who performs the ceremony is not a pure virgin, a bad year is expected (Pausanias 1979: 7:19:1-3, Connelly 2007, p. 41, Pailler 1997, pp. 516523, Dillon 2002, pp. 37-106, 236-67, Ogden 2013a, pp. 203-6, 347-59). This attitude toward holy women gone astray is embedded in the image of Medusa, stressing the impossibility of the two worlds coexisting, which means therefore that she must die.

Although in these myths Medusa must die, her head lives on. On a mosaic from Piraeus (see Figure 15), for example, Medusa's head manifests powerful supernatural protection. This does not contradict the culturally ingrained fear of her image, since apotropaios invites opposite functions for the same image: the image is of a threatening figure, but it also is supposed to turn the threat away. 


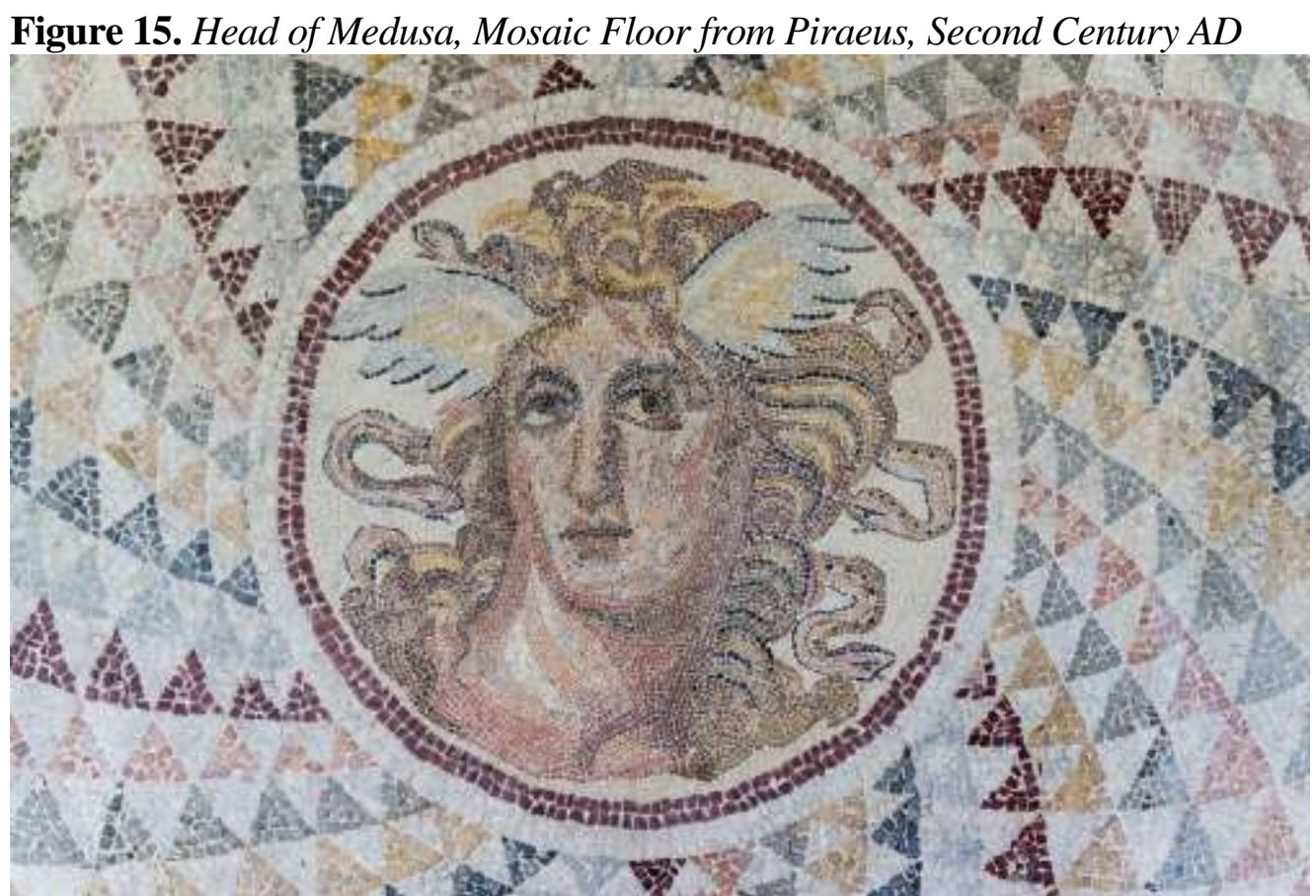

Source: Athens Archaeological Museum. public-domain.

In narrated visual evidence from the end of the third century BC until Late Antiquity, Medusa appears only once and only with a portion of her narrative. As her narrated depiction vanished, the emblem of her head became a best seller, directly influenced by the perception of the power of her image in Greco-Roman culture. Presenting Medusa alive constituted a threat to the beholder. Therefore, her story could be told and her head could be displayed for protection, but her image as a living being is far too dangerous and so off-limits. Thus the meaning of Medusa's myth and images highlight that what she stands for-a female violation of patriarchal order-has to die in order for her to be controlled. Her death is a didactic tool for a male-dominated culture, indicating that deviating from its norms will not be tolerated. So her image can exist only as a tool for prevention of harm, fire against fire. In this way Medusa not only turns away demons from without, but also protects against social deviations from within ${ }^{5}$.

\section{Perseus: A Man between Two Opposite Women}

Perseus is the typical Greek hero that stands between Medusa and Andromeda and their two myths that revolve around a woman and a dragon. Paralleling these two myths in the story of Perseus illuminates the meaning of "the woman and the dragon" motif in Greco-Roman cultural context. The main theme of these myths is good women who are suitable for marriage versus women who are defiled and forbidden. Andromeda, "the good woman", is completely passive; she is bound to

${ }^{5}$ For an example of female monsters' educational role in ancient Greece, see Johnston (1995, pp. 361-87). 
marriage or death, which are one and the same. The dragon is approaching death, striving for a union with her, but a union with a man also means the death of her old identity and her rebirth as a new person. On the other side is Medusa, "the defiled woman," who is sworn to chastity as the priestess of the dragon-goddess Athena, but her vow is broken when Poseidon rapes her. She now has knowledge of two distinct worlds - the world of the holy (sky) and the world of the defiled (underground), which makes her a categorical threat. At the moment of the rape, Medusa is transformed from a dragon mistress into a grotesque fused with the dragon; she is both bird and snake, above and below, possessing absolute power of destruction, fertility, and rejuvenation. This idea is conceptualized in Medusa's head emblem, as seen in the Medusa Rondanini and the mosaic floor from Piraeus (see Figures 13 and 15), which both show her not only with serpents in her hair but also with wings. She is too powerful and therefore must not only be isolated and killed, but also, and more importantly, brought under male control. That is why her still-functioning head must be separated from her body, eventually reclaimed by the androgynous dragon-goddess Athena. Perseus is a role model for a male positioned between these two female figures that has to react correctly to each one. His behavior is a didactic tool to educate men about two opposite types of women: those suitable and unsuitable for marriage. To fully understand the power of these myths one must understand the sacred relationship between a woman and a dragon in Greco-Roman cultures. Ogden, in his survey of dragon mistresses, presents a number of rituals and events in which a prophetic snake was groomed, served, and given sacrifice by women of varying degrees of chastity. For example, the oikouros ophis is the holy serpent guardian of the Parthenon, and was tended by the virgin priestess of Athena; it was sometimes considered a metamorphosis of the goddess herself (Herodotus 2008, p. 501: 8:41, Ogden 2013a, pp. 203-204). The prophetic snakes, seen as sons of Python, were tended by virgin priestesses in the sanctuary of Apollo in Epirus (Aelian 2011, p. 101: 11:2). The Pythia-the Oracle of Apollo at Delphi - was also a virgin female priestess who could hear Python's whispers and was inspired by the fumes of the creature's rotten corpse (Nonnus of Panopolis 1962-1963: 9:547-552, Hyginus 2002, pp. 116-117: 140, Parke and Wormell 1956, pp. 20-21, Rohde 2010, p. 97). The elderly priestess of Eileithyia was the only person authorized to enter the sanctuary of the dragon Sosipolis (Pausanias 1979: 6:20:2-6). Pailler summarizes the power of the Vestal Virgins as "priestess[es] of the serpent" and outlines the Roman and Etruscan roots for the virgin-dragon connection ${ }^{6}$. Some women were sworn to chastity for their entire life, others had to avoid intercourse (kathareusai or inter alia) for only several days before a ceremony, such as in the Thesmophoria festival (Lucian of Samosata 1915, pp. 359-360: 2:1). The great amount of evidence that the virgindragon relationships were a sacred interaction is overwhelming. Such interactions led to holy events of oracular knowledge, protection, and prosperity.

Some men were also dragons' attendants, but this analysis focuses on the feminine aspect of these phenomena and attests to the copious evidence regarding the importance of women in this respect. For example, the Delphic Pythia is an

\footnotetext{
6“Prêtresse du serpent” see Pailler (1997, pp. 517-575).
} 
exception of a female priestess in a masculine temple (Connelly 2007, p. 2). Among the gods, there are two female goddesses-Athena/Minerva and Hygieia/ Salus - who are regularly associated with dragons as their attribute and maintain eternal virginity. The realm of the gods, however, is more complex, for there is Apollo, whose attribute is Python, and also Asclepius with the serpent on his staff (Cook 1914-1940, vol. 2, pp. 182-183, 186-197, Schouten 1967, Mitropoulou 1977, pp. 183-197, Edelstein and Edelstein 1998, vol. 2, pp. 87-90, Ogden 2013a, pp. 192-214). Female goddesses who are associated with dragons, however, are mostly sworn to chastity, while male gods are not. Consequently, the interaction between a virgin and a dragon was undoubtedly considered sacred.

The dragon in this context is an allegorical symbol of the great goddess. The cave of the dragon is the womb of the earth, and the dragon is a representative metamorphosis of the great goddess. It is no wonder then that fertility goddesses, such as Wadget, Isis, Demeter/Ceres, Bona Dea, Vesta, and so many more, have been described as accompanied by, led by, or transformed into a dragon. This work presumes the dragon to be a unifying symbol of women and their identities, separate individuals with needs, wishes, and power of their own. The removal of the dragon from the scenario by the hero manifests not only the masculine prevailing over the feminine, but also the erasure of a woman's personal identity, as she is transitionally blended into the identity of her male "superior."

All myths related to Perseus notably revolve around the issue of marriage. Danaë's father, Acrisius, deprives his daughter of marriage by imprisoning her; King Polydectes desires Danaë for marriage, but is legally blocked by Perseus; Perseus asks for permission to marry Andromeda from her father; and Medusa's head petrifies both Phineus - the failed husband-to-be - and Polydectes. Furthermore, artistic depictions emphasize the "bride of death" theme. Hence, the meaning and value of this myth-sequence lies in the theme of marriage and legal interactions between a man and a woman.

The Perseus myth sequence spans the range of women's behavior in GrecoRoman cultures, from the best to the worst, and demonstrates the masculine overpowering the feminine. The dragon symbolizes feminine power, which the man has to wrest from the woman - sever her identity - in order to gain control over her. In "the good woman" case, the separation occurs before the union of the woman and the dragon (symbolizing her power and identity); in "the bad woman" case, the male occupation takes place after the woman already possesses tremendous powers, so the hero must take more aggressive action-decapitation (Culpepper 1986, pp. 22-24, Bowers 1990, pp. 217-235, Dexter 2010, pp. 25-41). These myths manifest the ancient cultural anxiety surrounding the sacred connection of women and dragons, which is relevant during the Greco-Roman era and beyond. Perseus, signifying the protypical Greek male, is sent to perform two patriarchal tasks: slay Medusa-the ultimate female threat of a sacred-defiled woman who is too powerful-and wed a good girl, Andromeda, by preventing her death and her sacred bonding with the dragon, thereby making her suitable to wed (with permission from her father).

The artistic evidence shows an interesting phenomenon: only in the Hellenistic age, for approximately two centuries, is there a battle between Perseus 
and Ketos. The two centuries prior to Hellenistic times present Medusa's actual slaughter. Imperial Rome is almost devoid of visual representations of combat interactions with the dragon, who, in images, is either physicially too far away, dead, or iconic.

Medusa's isolation is not only mythical, but is also manifested in her severedhead icon and described by her location as a socially marginalized character. Gananath Obeyesekere's anthropological investigation of present-day Medusa-like women, who are located on the margins of society, is highly useful for understanding the Medusa figure as a powerful woman unbound from the social structure (Obeyesekere 1981).

\section{Conclusion}

To conclude, several claims have emerged. The meaning of the "bride of death" theme is seen in wedding/funeral gifts that were paradigmatically altered by the sign of a dragon. Andromeda is located in a cave's entrance, the liminal location between the realm of life and death, and at the entrance of the symbolic womb. The paradigmatic change in Medusa from ugly to beautiful differentiates between her dragon and feminine aspects and explicitly posits her inherent feminine danger. Medusa unifies binary concepts of the realms of above and below, birth and death, danger and protection, holiness and defilement, which could not exist without male-dominant cultural context, and her myth and artistic images reflect that the way that her power is steeped in fear. Woman-with-dragon images continue to elicit fear and discomfort and raise questions about the power of the woman-dragon bond. This article in some ways supplements Hélène Cixous's "Le Rire de la Mèduse" (The Laugh of Medusa) and outlines that the myth of Perseus demonstrates the process through which men gradually took possession of women and stripped them of their power in the ancient GrecoRoman world and shows the reasons that Medusa had to die (Cixous 1975).

\section{References}

Achilles Tatius (1961) Achilles tatius: Leucippe et Clitophon (Achilles tatius: Leucippe and Clitophon). Translated by S Gaseles. London: Heinemann.

Aelian (2011) Aelian's on the Nature of Animals. Translated by G McNamee. San Antonio TX: Trinity University Press.

Apollodorus of Athens (2008) Bibliotheca. Translated by RC Seaton. Adelaide: University of Adelaide Library.

Apollonius of Athens (2008) Bibliotheca. Translated by R Hard. Oxford and New York: Oxford University Press.

Baert B (2019) About sieves and sieving: motif, symbol, technique, paradigm. Berlin: De Gruyter.

Baert B, Lehmann AS, Akkerveken JVD, Schalley N (2011) New perspectives in iconology: visual studies and anthropology. Brussels: Academic and Scientific Publishers. 
Barringer JM (1991) Europa and the Nereids: wedding or funeral? American Journal of Archaeology 95(4): 657-667.

Belson JD (1980) The Medusa Rondanini: a new look. American Journal of Archaeology 84(3): 373-378.

Bowers SR (1990) Medusa and the female gaze. National Women's Studies Association Journal 2(2): 217-235.

Burkert W (1988) Oriental and Greek mythology: the meeting of parallels. In J Bremmer (ed.), Interpretations of Greek Mythology. London: Routledge.

Buschor E (1958) Medusa Rondanini. Stuttgart: Kohlhammer.

Carden R (Ed.) (1974) The papyrus fragments of Sophocles: an edition with prolegomena and commentary. Berlin: De Gruyter.

Carter JB (1987) The masks of Ortheia. American Journal of Archaeology 91(3): 355383.

Cassius Dio (2015) Roman history. Translated by E Cary and HB Foster. Cambridge, MA: Harvard University Press.

Cixous H (1975) Le rire de la Méduse (The laughter of the Medusa). L'arc 61: 39-54.

Connelly JB (2007) Portrait of a priestess: women and ritual in ancient Greece. Princeton, NJ: Princeton University Press.

Cook AB (1914-1940) Zeus: a study in ancient religion. 3 Volumes. Cambridge, UK: Cambridge University Press.

Culpepper EE (Winter-Spring 1986) Ancient gorgons: a face for contemporary women's rage. Women of Power 3: 22-24.

D’Alconzo N (2014) A Diptych by Evanthes: Andromeda and Prometheus (Ach. Tat. 3,68). Ancient Narrative 11: 75-91.

DeVault ML (1990) Talking and listening from women's standpoint: feminist strategies for interviewing and analysis. Social Problems 37(1): 96-116.

Demand N (1994) Birth, death, and motherhood in classical Greece. Baltimore: Johns Hopkins University Press.

Deonna W (1949) L'arbre, le serpent et la jeune femme (The tree, the snake and the young woman). In H Gregoire (ed.), Mélanges Henri Grégoire, 197-205. Brussels: Secrétariat des Éditions de l'Institut.

Dexter MR (Spring 2010) The ferocious and the erotic: 'beautiful' medusa and the neolithic bird and snake. Journal of Feminist Studies in Religion 26(1): 25-41.

Dillon M (2002) Girls and women in classical Greek religion. London: Routledge.

Dillon S, James SL (Eds.) (2015) A companion to women in the ancient World. Malden, MA: Wiley-Blackwell.

Diodorus Siculus (1700) The historical library of Diodorus the Sicilian in fifteen books. Translated by G Booth. London: Edward Jones for Awnsham and John Churchill and Edw. Castle.

Dowden K (1989) Death and the maiden: girls' initiation rites in Greek mythology. London: Routledge.

Edelstein EJ, Edelstein L (Eds.) (1998) Asclepius: collection and interpretation of the testimonies. With Introduction by GB Ferngren. Baltimore: Johns Hopkins University Press.

Eratosthenes of Cyrene (2013) Catastérismes (Catasterisms). Edited and with Introduction and Notes by JP i Massana. Translated and with Notes by A Zucker. Paris: Les Belles Lettres.

Euripides (2004) Selected fragmentary plays. Translated and with Introduction and Commentary by C Collard, MJ Cropp, J Gibert. Warminster: Aris and Phillips.

Frontisi-Ducroux F (1995) Du masque au visage: aspects de l'identité en Grèce ancienne (From mask to face: aspects of identity in ancient Greece). Paris: Flammarion. 
Gantz T (1996) Early Greek myth. Baltimore: Johns Hopkins University Press.

Garber M, Vickers NJ (Eds.) (2003) The Medusa reader. New York: Routledge.

Gardner JF (1986) Women in Roman law and society. London: Croom Helm.

Gershenson D (1989) The beautiful gorgon and Indo-European parallels. Mankind Quarterly 29(4): 373-390.

Harrison EB (1977) Alkamenes' sculptures for the hephaisteion: part I, the cult statues. American Journal of Archaeology 81(2): 162-175.

Herodotus (2008) The histories. Translated by R Waterfield. Introduction and Notes by C Dewald. Oxford: Oxford University Press.

Hesiod (2018a) The shield: catalogue of women; other fragments. Edited and Translated by GW Most. Cambridge, MA: Harvard University Press.

Hesiod (2018b) Theogony; works and days; testimonia. Edited and Translated by GW Most. Cambridge, MA: Harvard University Press.

Hoffmann H (1963) Museum of fine arts. Boston: Billetin.

Hyginus (2002) Fabulae. Edited by PK Marshal. Munich: KG Saur.

Jacoby F (Ed.) (1923) Die Fragmente der griechischen Historiker (FGrH) (The fragments of the Greek historians). Leiden: Brill.

Jenkins I (1983) Is there life after marriage? A study of the abduction motif in vase paintings of the Athenian wedding ceremony. Bulletin of the Institute of Classical Studies 30(1): 137-45.

Johnston SI (1995) Defining the dreadful: remarks on the Greek child-killing demon. In M Meyer and P Mirecki (eds.), Ancient Magic and Ritual Power, 361-387. Leiden: Brill.

Keuls EC (1976) Aspetti religiosi della Magna Grecia nell'eta Romana (Religious aspects of Magna Graecia in the Roman age). Atti del convengo di studi sulla Magna Grecia. Taranto 15: 439-458.

Lexicon Iconographicum Mythologiae Classicae - LIMC (1981-1999) Lexicon Iconographicum Mythologiae Classicae. 9 Volumes. Zurich: Artemis.

Liepe LE (Ed.) (2019) The locus of meaning in medieval art: iconography, iconology, and interpreting the visual imagery of the middle ages. Michigan: Medieval Institute Publications.

Lovén LL, Strömberg A (Eds.) (2010) Ancient marriage in myth and reality. Newcastle upon Tyne, UK: Cambridge Scholars.

Lucian of Samosata (1915) Lucian of Samosata. Translated by AM Harmon. Cambridge, MA: Harvard University Press.

Lucian of Samosata (2009) The works of Lucian of Samosata. Translated by HW Fowler, FG Fowler. Adelaide: University of Adelaide Library.

Mayerson P (1971) Classical mythology in literature, art, and music. Lexington, MA: Xerox Corporation.

Milnor K (2005) Gender, domesticity, and the age of Augustus: inventing private life. Oxford: Oxford University Press.

Mitropoulou E (1977) Deities and heroes in the form of snakes. Athens: Pyli.

Nonnus of Panopolis (1962-1963) Dionysiaca. Translated by WHD Rouse. Introduction by HJ Rose. Notes by HJ Rose, LR Lind. 3 Volumes. Loeb Classical Library. London: Heinemann; Cambridge, MA: Harvard University Press.

Obeyesekere G (1981) Medusa's hair: an essay on personal symbols and religious experience. Chicago: University of Chicago Press.

Ogden D (2008) Perseus. London: Routledge.

Ogden D (2013a) Drakōn: dragon myth and serpent cult in the Greek and Roman worlds. Oxford: Oxford University Press. 
Ogden D (2013b) Dragons, serpents and slayers in the classical and early Christian worlds: a sourcebook. Oxford: Oxford University Press.

Ovid (1998) Metamorphoses. Translated by AD Melville. Introduction and Notes by EJ Kenney. Oxford and New York: Oxford University Press.

Padel R (1992) In and out of the mind: Greek images of the tragic self. Princeton, NJ: Princeton University Press.

Pailler JM (1997) La vierge et le serpent de la trivalence à l'ambiguité (The virgin and the serpent the trivalence of ambiguity). Mélanges de l'École Française de Rome Antiquité 109(2): 513-575.

Panofsky E (1955) Meaning in the visual arts. Chicago: University of Chicago Press.

Parisinou E (2000) The light of the gods: the role of light in archaic and classical Greek cult. London: Duckworth.

Parke HW, Wormell DEW (1956) The Delphic oracle. Oxford: Basil Blackwell.

Pausanias (1979) Guide to Greece. Translated and Introduction P Levi. Illustrations by J Newberry. Maps and Plans by J Lacey. Harmondsworth, UK: Penguin.

Phillips KM (January 1968) Perseus and Andromeda. American Journal of Archaeology 72(1): $1-23$.

Pindar (1997) Olympian Odes. Pythian Odes. Edited and Translated by WH Race. Cambridge, MA: Harvard University Press.

Pritchard JB (Ed.) (1969) Ancient near eastern texts: relating to the old testament. Princeton, NJ: Princeton University Press.

Reinach S (1905) Le serpent et la femme (The serpent and the woman). L'anthropologie 16: $178-80$.

Renan Y (2001) Goddesses and Heroes: On the Limits of Power. Tel-Aviv: Am Oved.

Ribbeck O (Ed.) (1892) Tragicorum romanorum fragmenta (TRF). Leipzig: Teubner.

Rohde E (2010) Psyche: The cult of souls and the belief in immortality among the Greeks. New York: Routledge.

Roscher WH (1896) Die Gorgonen und Verwandtes (The Gorgons and their relatives). Leipzig: Teubner.

Saintyves P (1908) Les vierges mères et les naissances miraculeuses (Virgin mothers and miraculous births). Paris: Nourry.

Schmidt M (1960) Der Dareiosmaler und sein Umkreis: Untersuchungen zur spätapulischen Vasenmalerei (The Dareios painter and his circle: investigations into late Apulian vase painting). Münster: Aschendorffsche Verlagsbuchhandlung.

Schouten J (1967) The Rod and serpent of Asklepios, symbol of medicine. Translated by ME Hollander. Amsterdam: Elsevier.

Scylax (2011) Pseudo-Skylax's periplous: the circumnavigation of the inhabited world text. Translation and Commons G Shipley. Exeter, UK: Bristol Phoenix.

Seaford R (1987) The tragic wedding. Journal of Hellenic Studies 107: 106-30.

Snell B (Ed.) (1971-2004) Tragicorum Graecorum fragmenta (TrGF) (Fragments of Greek tragedy). Göttingen: Vandenhoeck and Ruprecht.

Suetonius (1998) Lives of the Caesars. Translated by JC Rolfe. Cambridge, MA: Harvard University Press.

Taplin O (2007) Pots and plays: interactions between tragedy and Greek vase-painting of the fourth century BC. Los Angeles: J. Paul Getty Museum.

Tefnin R (2003) Les regards l'image des origines jusqu'à Byzance (Regarding the image the origins until Byzantium). Anvers: Fonds Mercator.

Topper K (2007) Perseus, the maiden medusa, and the imagery of abduction. Hesperia: Journal of the American School of Classical Studies at Athens 76(1): 73-105.

Von Blanckenhagen PH, Alexander C (1962) The paintings from Boscotrecase. With Appendix by G Papadopulos. Heidelberg: Kerle. 
Von Blanckenhagen PH, Alexander C (1990) The Augustan villa at Boscotrecase. With Contributions by JR Mertens, C Faltermeier. Mainz am Rhein: Von Zabern.

Warmington EH (1967) Remains of old Latin. London: Heinemann.

Watkins C (2001) How to kill a dragon: aspects of Indo-European poetics. Oxford: Oxford University Press.

Wilk SR (2000) Medusa. Oxford and New York: Oxford University Press.

Worthington I (2012) Alexander the Great: a reader. London: Routledge. 
